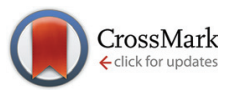

Cite this: Dalton Trans., 2016, 45, 13114

Received 6th May 2016,

Accepted 23rd May 2016

DOI: $10.1039 / \mathrm{c} 6 \mathrm{dt} 01782 \mathrm{~g}$

www.rsc.org/dalton

\section{Antiproliferative activity of ruthenium(II) arene complexes with mono- and bidentate pyridine-based ligands $\uparrow$}

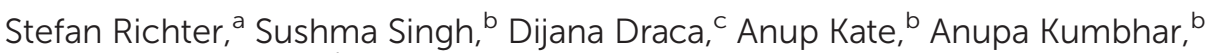 \\ Avinash S. Kumbhar, ${ }^{\text {b }}$ Danijela Maksimovic-Ivanic, ${ }^{c}$ Sanja Mijatovic, ${ }^{c}$ \\ Peter Lönnecke ${ }^{a}$ and Evamarie Hey-Hawkins*a
}

\begin{abstract}
A series of $\mathrm{Ru}^{\prime \prime}$ arene complexes of mono- and bidentate $\mathrm{N}$-donor ligands with carboxyl or ester groups and chlorido ancillary ligands were synthesised and structurally characterised. The complexes have a distorted tetrahedral piano-stool geometry. The binding interaction was studied with calf thymus DNA (CT-DNA) by absorption titration, viscosity measurement, thermal melting, circular dichroism, ethidium bromide displacement assay and DNA cleavage of plasmid DNA (pBR322), investigated by gel electrophoresis. The dichlorido complexes bind covalently to DNA in the dark, similar to cisplatin, while the monochlorido complexes bind covalently on irradiation, similar to cisplatin analogues. The compounds are selectively cytotoxic against several tumour cell lines and show specific nonlinear correlation between dose and activity. This phenomenon is closely related to their potential to act preferentially as inhibitors of cell division.
\end{abstract}

\section{Introduction}

Ruthenium complexes are emerging as promising alternatives to highly active but toxic platinum complexes as anticancer drugs, ${ }^{1}$ as corroborated by successful clinical trials of trans[tetrachlorido(dimethyl sulfoxide)imidazole ruthenium(III)] (NAMI-A), ${ }^{2-9}$ indazolium trans-[tetrachloridobis( $1 H$-indazole)ruthenium(III)] (KP1019) ${ }^{10-14}$ and sodium trans-[tetrachloridobis(1H-indazole)ruthenate(III)] (NKP1339). ${ }^{15,16}$ The mechanism involves the in vivo reduction of the $\mathrm{Ru}^{\mathrm{III}}$ prodrugs to the active $\mathrm{Ru}^{\mathrm{II}}$ complexes in the hypoxic tumour cells at lower $\mathrm{pH}$, which then bind to specific biomolecules to provide selective toxicity. ${ }^{17,18}$ The inherent properties of ruthenium, that is, variable oxidation states, stability in air, relative ease of preparation and purification, slow in vivo ligand exchange and lower toxicity, seem to be favourable compared to platinum. Several $\mathrm{Ru}^{\mathrm{II}}$ polypyridyl complexes which were initially developed as structure- and site-specific reversible DNA binding agents more recently found applications as cellular imaging agents. ${ }^{19-21}$

\footnotetext{
${ }^{a}$ Universität Leipzig, Institut für Anorganische Chemie, Johannisallee 29, 04103 Leipzig, Germany. E-mail: hey@uni-leipzig.de

${ }^{b}$ Department of Chemistry, Savitribai Phule Pune University, Pune-411007, India "Institute for Biological Research "Sinisa Stankovic", University of Belgrade, Bulevar despota Stefana 142, 11060 Belgrade, Serbia

$\dagger$ Electronic supplementary information (ESI) available. CCDC 1421200-1421204. For ESI and crystallographic data in CIF or other electronic format see DOI: 10.1039/c6dt01782g
}

The most widely studied organometallic ruthenium compounds are ruthenium arene and ruthenium cyclopentadienyl half-sandwich compounds with a piano-stool geometry, due to their structural diversity and varied binding modes to DNA. The first compound of this type was synthesised by Dale et al. by coordinating the known anticancer agent 1 - $\beta$-hydroxyethyl2-methyl-5-nitro-imidazole (metronidazole) to a ruthenium(II) benzene dichloride fragment resulting in better activity than metronidazole itself in an in vitro assay. ${ }^{22}$ This was followed by Sheldrick et al., who demonstrated that complexes of the type $\left[\mathrm{Ru}^{\mathrm{II}}\left(\eta^{6}\right.\right.$-arene)(LL)X $]$ (where $\mathrm{LL}=$ L-alanine and $\mathrm{L}$-alanine methyl ester and $\mathrm{X}=$ halide) are coordinated by nitrogen atom $\mathrm{N}^{7}$ of guanine derivatives. ${ }^{23}$ Thereafter, in pioneering work Sadler et $a .^{24-27}$ and Dyson et al. ${ }^{28-31}$ developed structureactivity relationships using $\left[\mathrm{Ru}^{\mathrm{II}}\left(\eta^{6} \text {-arene) }(\mathrm{en}) \mathrm{Cl}\right]^{+}\right.$(arene $=$ biphenyl (Biph), tetrahydroanthracene (THA), dihydroanthracene (DHA), para-cymene ( $p$-cym) or benzene; en = ethylenediamine) and the water-soluble $\left[\mathrm{Ru}^{\mathrm{II}}\left(\eta^{6}\right.\right.$-arene $\left.)(\mathrm{pta}) \mathrm{Cl}_{2}\right]$ complexes (pta $=$ 1,3,5-triaza-7-phosphatricyclo[3.3.1.1]-decane), respectively, which are considered to be the prototypes of anticancer $\mathrm{Ru}^{\mathrm{II}}$ arene complexes. Espino et al. have derived extensive structure-activity relationships for the anticancer properties of $\mathrm{Ru}^{\mathrm{II}}$ arene complexes with 2,4-diamino-(2-pyridyl)-1,3,5-triazine, ${ }^{32,33}$ phenanthrolines, ${ }^{34}$ aminophosphines, ${ }^{35}$ benzimidazole $^{35}$ and 2-aryldiazole. ${ }^{36}$ Recently, Wang et al. introduced $\mathrm{Ru}$ (arene)/BODIPY (BODIPY = boron dipyrromethene) hybrids, which on irradiation undergo fast release of BODIPY facilitating covalent binding of the resulting $\mathrm{Ru}^{\mathrm{II}}$ complex fragment to 
DNA, resulting in high ${ }^{1} \mathrm{O}_{2}$ quantum yields and DNA cleavage, and can thus act as a potential photoactivated anticancer agent (PACT). ${ }^{37}$ As shown by Mukherjee et al., the sterically encumbered imidazole-based Schiff base ligand $\mathrm{N}$-[(1H-imidazol-2-yl)methylene]-2,6-diisopropylaniline slowed the hydrolysis, and the corresponding ruthenium complex [RuCl( $p$-cym $)\{N$-\{(1H-imidazol-2-yl)methylene $\}$-2,6-diisopropylaniline $\}]$ exhibited better activity under hypoxia, strong resistance to glutathione in vitro and thus strong anticancer activity. ${ }^{38}$ Dyson et al. recently demonstrated that the coordinating mode (N,N versus $\mathrm{N}, \mathrm{O})$ and the substituents on $\mathrm{N}$-phenylpicolin- amide $^{39}$ or $\beta$-ketonamide ${ }^{40}$ ligands drastically affect the biological activity of the corresponding complexes. Complexes with N,N-coordinating ligands are hydrolysed quickly, show selective binding to guanine and therefore are cytotoxic, while complexes with N,O-coordinating ligands are not hydrolysed and therefore cannot be coordinated by guanine and are non-toxic.

For this reason, complexes of mono- (1-3) and bidentate (4-6) N-donor ligands (A-E) with free carboxyl acid and ester groups (Scheme 1) were synthesised, and their binding interaction with DNA was evaluated by absorption titration, vis-<smiles>Nc1ccc(C(=O)O)cc1</smiles><smiles>CCOC(=O)c1ccc(Nc2ccccn2)cc1</smiles><smiles>CNc1ccc(C(=O)O)cc1</smiles><smiles>O=C(O)CNCc1ccccn1</smiles><smiles>C=C(Nc1ccc(C(=O)O)cc1)c1ccccn1</smiles><smiles>CCOC(=O)c1cc(N[R](Cl)(Cl)Cl)ccc1C</smiles>

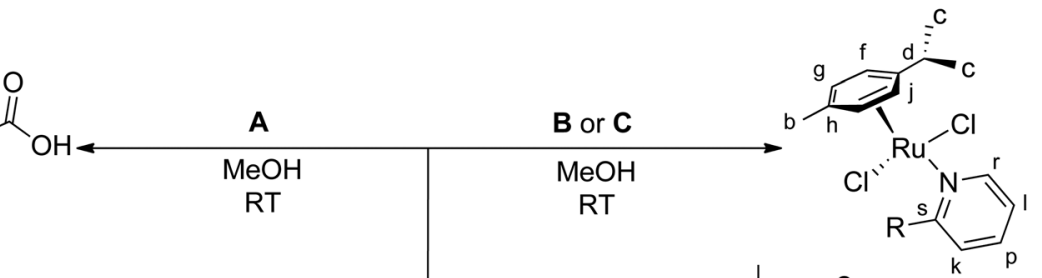

1

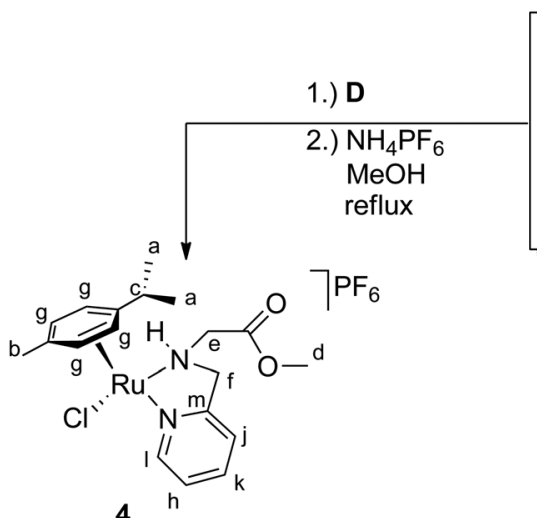

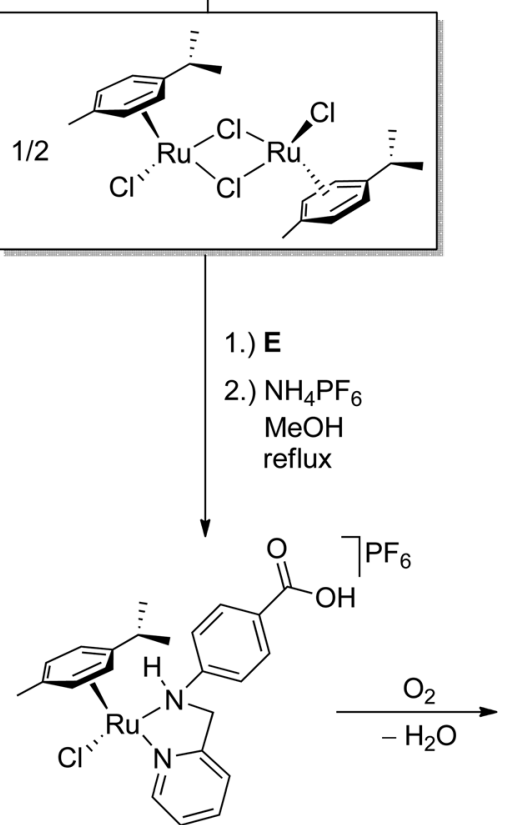

5
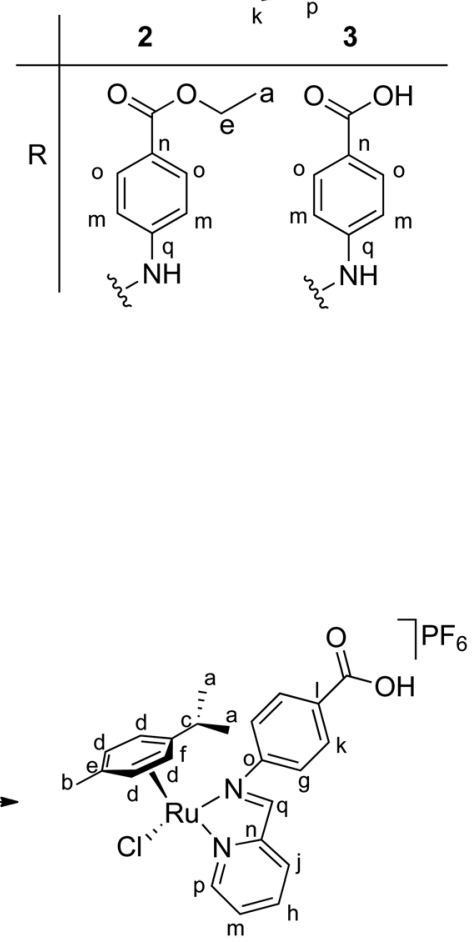

6

Scheme 1 Ligands A-E and synthesis of the Ru" complexes 1-6. 
cosity measurement, thermal melting, circular dichroism and ethidium bromide displacement assay. DNA cleavage was studied by gel electrophoresis, and cytotoxicity against human thyroid (8505C), melanoma (518A2), breast (MCF-7) and colon (SW-480) tumour cell lines was evaluated. Cytotoxic compounds with free carboxyl groups are potentially interesting for conjugation to tumour-targeting peptides for achieving better tumour selectivity. ${ }^{41,42}$

\section{Experimental section}

\section{Materials}

$\mathrm{RuCl}_{3} \cdot 3 \mathrm{H}_{2} \mathrm{O}$ was purchased from Johnson Matthey. The precursor complex $\left[\left\{\mathrm{RuCl}_{2}(p \text {-cym })\right\}_{2}\right]\left(p \text {-cym }=1-{ }^{\mathrm{i}} \mathrm{Pr}-4-\mathrm{Me}-\mathrm{C}_{6} \mathrm{H}_{4}\right)^{43}$ and ligands $\mathbf{B},{ }^{44} \mathbf{C}^{44}$ and $\mathbf{D}^{45}$ were prepared according to literature procedures. Yields, properties, NMR $\left({ }^{1} \mathrm{H},{ }^{13} \mathrm{C}\right)$ and IR data of B-D are given in the ESI. $\dagger$ The ligand 4-aminobenzoic acid (A, 4-ABA) was purchased from Sigma Aldrich. Calf thymus DNA (CT-DNA) and plasmid $p B R 322$ DNA were purchased from SRL (India). Supercoiled $p B R 322$ DNA (CsCl) purified was obtained from Bangalore Genei (Bangalore, India) and used as received. Ethidium bromide (EtBr) was purchased from S.D. Fine Chemicals, Mumbai, India. Deionised water was used for the preparation of the buffer solutions.

\section{Physical measurements}

All complexation reactions were performed under $\mathrm{N}_{2}$ atmosphere by using standard Schlenk techniques. Solvents were dried with the solvent purification system SPS-800 SERIES (company MBRAUN). NMR spectra $\left({ }^{1} \mathrm{H},{ }^{13} \mathrm{C}\right)$ were recorded at $27{ }^{\circ} \mathrm{C}$ on a Bruker 300 or DRX 400 spectrometer. Chemical shifts are relative to internal standard (TMS). Numbering schemes are included in Scheme 1. IR spectra of the complexes were recorded as $\mathrm{KBr}$ disks on a Perkin Elmer FTIR Spektrum 2000 spectrometer. The elemental analyses were recorded on a Heraeus Vario Analyser and the melting points were determined in capillaries using a Gallenkamp instrument. Mass spectra were obtained as ESI MS with an FT ICR mass spectrometer (Bruker Daltonics).

Synthesis of 4 -[( pyridin-2-ylmethyl)amino]benzoic acid $\cdot \mathbf{H C l}$ (E.HCl). A solution of 2-pyridinecarbaldehyde $(4.28 \mathrm{~g}$, $40 \mathrm{mmol})$ in ethanol $(20 \mathrm{ml})$ was added over $30 \mathrm{~min}$ to a solution of 4-aminobenzoic acid (A, $5.48 \mathrm{~g}, 40 \mathrm{mmol})$ and $\mathrm{KOH}$ $(2.24 \mathrm{~g}, 40 \mathrm{mmol})$ in water $(20 \mathrm{ml})$ cooled with an ice bath. The cooled solution was stirred for another 30 minutes, then warmed to room temperature. A solution of $\mathrm{NaBH}_{4}(1.48 \mathrm{~g}$, $40 \mathrm{mmol})$ in water $(10 \mathrm{ml})$ was slowly added and the solution stirred for $60 \mathrm{~min}$. After completion of the reaction the $\mathrm{pH}$ value was adjusted with aqueous $\mathrm{HCl}$ solution $(20 \mathrm{ml}, 2 \mathrm{M})$ to pH 3, at which violent gas evolution was observed. The solvent was removed in vacuo to give a dirty yellow solid. The solid was extracted three times with hot methanol $(3 \times 30 \mathrm{ml})$, the combined extracts were reduced to $20 \mathrm{ml}$ and the light yellow product precipitated. The product was isolated and washed with diethyl ether $(15 \mathrm{ml})$ and dried in vacuum. Yield: $6.0 \mathrm{~g}$
(65\%). Properties: light yellow, microcrystalline solid; soluble in water; insoluble in $n$-hexane, diethyl ether. ${ }^{1} \mathrm{H}$ NMR (300 MHz, DMSO- $\left.\mathrm{d}_{6}\right): \delta 4.46\left(\mathrm{~s}, 2 \mathrm{H}, \mathrm{CH}_{2}{ }^{\mathrm{a}}\right), 6.62\left({ }^{\prime} \mathrm{d}\right.$ ', $\left.2 \mathrm{H}, \mathrm{CH} H^{\mathrm{b}}\right)$, 7.18 (s, br, 1H, NH), 7.29 ('t', $\left.1 \mathrm{H}, \mathrm{CH}^{\mathrm{e}}\right), 7.37$ ('d', $\left.1 \mathrm{H}, \mathrm{C} H^{\mathrm{d}}\right), 7.67$ ('d', $\left.2 \mathrm{H}, \mathrm{CH}^{\mathrm{f}}\right), 7.78\left(\right.$ 't', $\left.1 \mathrm{H}, \mathrm{CH}^{\mathrm{g}}\right), 8.55$ ('d', $\left.1 \mathrm{H}, \mathrm{CH} H^{\mathrm{h}}\right), 12.05(\mathrm{~s}$, br, $1 \mathrm{H}, \mathrm{OH}) .{ }^{13} \mathrm{C}\left\{{ }^{1} \mathrm{H}\right\}$ NMR (75 MHz, DMSO-d ${ }_{6}$ ): $\delta 47.8$ (s, $\left.\mathrm{CH}_{2}{ }^{\mathrm{a}}\right), 111.4\left(\mathrm{~s}, \mathrm{CH} H^{\mathrm{b}}\right), 117.6\left(\mathrm{~s}, C^{\mathrm{c}}\right), 121.4\left(\mathrm{~s}, C \mathrm{H}^{\mathrm{d}}\right), 122.5(\mathrm{~s}$, $\left.C \mathrm{H}^{\mathrm{e}}\right), 131.2\left(\mathrm{~s}, C \mathrm{H}^{\mathrm{f}}\right), 137.3\left(\mathrm{~s}, C \mathrm{H}^{\mathrm{g}}\right), 148.8\left(\mathrm{~s}, C \mathrm{H}^{\mathrm{h}}\right), 152.3(\mathrm{~s}$, $\left.C^{\mathrm{j}}\right), 158.9\left(\mathrm{~s}, C^{\mathrm{k}}\right), 167.6(\mathrm{~s}, C \mathrm{O}) .{ }^{13} \mathrm{C}\left\{{ }^{1} \mathrm{H}\right\}$ NMR $\left(75 \mathrm{MHz}, \mathrm{D}_{2} \mathrm{O}\right)$ : $\delta 48.2\left(\mathrm{~s}, \mathrm{CH}_{2}\right.$ ), 111.7 (s, $\left.\mathrm{CH}\right), 117.9$ (s, C), 121.8 (s, $\left.C \mathrm{H}\right), 122.8$ (s, $C \mathrm{H}), 131.6$ (s, $C \mathrm{H}), 137.6$ (s, $C \mathrm{H}), 149.2(\mathrm{~s}, C \mathrm{H}), 152.7$ (s, C), 159.3 (s, C), 167.9 (s, CO). IR: $\tilde{\nu}\left(\mathrm{cm}^{-1}\right) 3384(\mathrm{~s}), 2963(\mathrm{w})$, $2545(\mathrm{w}), 2363(\mathrm{w}), 1667$ (s), $1606(\mathrm{~s}), 1528(\mathrm{~m}), 1474(\mathrm{~m}), 1435$ (m), 1417 (m), $1316(\mathrm{~m}), 1290(\mathrm{~s}), 1175$ (s), 1089 (w), $840(\mathrm{w})$, $776(\mathrm{~m}), 765(\mathrm{~m})$.

\section{Synthesis of complexes 1-6}

Synthesis of $\left[\operatorname{RuCl}_{2}(\boldsymbol{p}\right.$-cym)(A)] (1). The synthesis of the complex $\left[\operatorname{RuCl}_{2}(p\right.$-cym $\left.)(4-\mathrm{ABA})\right]$ (1) was carried out by the literature method. ${ }^{46}$ Yield: $110 \mathrm{mg}(75 \%)$. Properties: orange solid; soluble in DMSO, DMF; insoluble in methanol, $n$-hexane, diethyl ether.

Synthesis of $\left[\operatorname{RuCl}_{2}\left(p\right.\right.$-cym)(B)] (2) and $\left[\operatorname{RuCl}_{2}(p\right.$-cym)(C)] (3). $\left[\left\{\operatorname{RuCl}_{2}(p \text {-cym })\right\}_{2}\right](100 \mathrm{mg}, 0.16 \mathrm{mmol})$ and ligand $\mathbf{B}(80 \mathrm{mg}$, $0.33 \mathrm{mmol})$ or $\mathbf{C}(86 \mathrm{mg}, 0.4 \mathrm{mmol})$ were dissolved in methanol $(8 \mathrm{ml})$. After stirring for $20 \mathrm{~min}$ at room temperature a light orange solid precipitated. The mixture was stirred for another $8 \mathrm{~h}$ for completion. Then the precipitate was filtered off, washed with diethyl ether $(5 \mathrm{ml})$ and dried in vacuum.

[ $\mathrm{RuCl}_{2}(\boldsymbol{p}$-cym)(B)] (2). Yield: $110 \mathrm{mg}$ (61\%); light orange powder; soluble in DMSO; insoluble in methanol, $n$-hexane and diethyl ether. M.p. $177{ }^{\circ} \mathrm{C}$ (decomp, orange to black). Elem. Anal. (found (calcd), \%): $\mathrm{C}_{24} \mathrm{H}_{28} \mathrm{Cl}_{2} \mathrm{~N}_{2} \mathrm{O}_{2} \mathrm{Ru}$ (548.47), C 52.18 (52.56), H 5.06 (5.15), N 5.00 (5.11). ${ }^{1} \mathrm{H} \quad \mathrm{NMR}$ (400 MHz, DMSO-d $\left.\mathrm{d}_{6}\right): \delta 1.19\left(\mathrm{~d},{ }^{3} \mathrm{~J}_{\mathrm{H}, \mathrm{H}}=6.9 \mathrm{~Hz}, 6 \mathrm{H}, \mathrm{CH}_{3}{ }^{\mathrm{c}}\right), 1.31$ $\left(\mathrm{t},{ }^{3} \mathrm{~J}_{\mathrm{H}, \mathrm{H}}=7.1 \mathrm{~Hz}, 3 \mathrm{H}, \mathrm{CH}_{3}{ }^{\mathrm{a}}\right), 2.09\left(\mathrm{~s}, 3 \mathrm{H}, \mathrm{CH}_{3}{ }^{\mathrm{b}}\right), 2.84\left(\mathrm{p},{ }^{3} \mathrm{~J}_{\mathrm{H}, \mathrm{H}}=\right.$ $\left.6.9 \mathrm{~Hz}, 1 \mathrm{H}, \mathrm{C} H^{\mathrm{d}}\right), 4.27\left(\mathrm{q},{ }^{3} J_{\mathrm{H}, \mathrm{H}}=7.1 \mathrm{~Hz}, 2 \mathrm{H}, \mathrm{CH}_{2}{ }^{\mathrm{e}}\right), 5.80(\mathrm{~m}$, $4 \mathrm{H}, \mathrm{CH}^{\mathrm{f}}, \mathrm{C} H^{\mathrm{g}}$ ), 6.86 ('t', $1 \mathrm{H}, \mathrm{C} H^{\mathrm{l}}$ ), 6.93 ('d', $1 \mathrm{H}, \mathrm{C} H^{\mathrm{k}}$ ), 7.64 ('t', $\left.1 \mathrm{H}, \mathrm{C} H^{\mathrm{p}}\right), 7.85\left(\mathrm{~m}, 4 \mathrm{H}, \mathrm{CH}^{\mathrm{m}}, \mathrm{CH}^{\mathrm{o}}\right), 8.23\left({ }^{\prime} \mathrm{d}\right.$ ' $\left.1 \mathrm{H}, \mathrm{C} H^{\mathrm{r}}\right), 9.54(\mathrm{~s}$, $1 \mathrm{H}, \mathrm{NH})$.

${ }^{13} \mathrm{C}\left\{{ }^{1} \mathrm{H}\right\}$ NMR (75 MHz, DMSO- $\left.\mathrm{d}_{6}\right): \delta 14.3\left(\mathrm{~s}, \mathrm{CH}_{3}{ }^{\mathrm{a}}\right), 17.8(\mathrm{~s}$, $\left.\mathrm{CH}_{3}{ }^{\mathrm{b}}\right), 21.5\left(\mathrm{~s}, \mathrm{CH}_{3}{ }^{\mathrm{c}}\right), 39.9\left(\mathrm{~s}, \mathrm{CH}^{\mathrm{d}}\right), 60.0\left(\mathrm{~s}, \mathrm{CH}_{2}{ }^{\mathrm{e}}\right), 86.5(\mathrm{~s}$, $\left.C \mathrm{H}^{\mathrm{f}}\right), 86.3\left(\mathrm{~s}, C \mathrm{H}^{\mathrm{g}}\right), 100.1\left(\mathrm{~s}, C^{\mathrm{h}}\right), 106.4\left(\mathrm{~s}, C^{\mathrm{j}}\right), 111.8\left(\mathrm{~s}, \mathrm{CH}^{\mathrm{k}}\right)$, $115.5\left(\mathrm{~s}, C \mathrm{H}^{\mathrm{l}}\right), 116.5\left(\mathrm{~s}, C \mathrm{H}^{\mathrm{m}}\right), 120.8\left(\mathrm{~s}, C^{\mathrm{n}}\right), 130.3\left(\mathrm{~s}, C^{\mathrm{o}}\right), 137.6$ $\left(\mathrm{s}, C \mathrm{H}^{\mathrm{p}}\right), 146.2\left(\mathrm{~s}, C \mathrm{H}^{\mathrm{q}}\right), 147.2\left(\mathrm{~s}, C \mathrm{H}^{\mathrm{r}}\right), 155.1\left(\mathrm{~s}, C^{\mathrm{s}}\right), 165.6(\mathrm{~s}$, CO). IR: $\tilde{\nu}\left(\mathrm{cm}^{-1}\right) 3444(\mathrm{~s}), 3222(\mathrm{~s}), 1712(\mathrm{~s}), 1603(\mathrm{~s}), 1568(\mathrm{~m})$, $1528(\mathrm{~m}), 1464(\mathrm{~m}), 1445(\mathrm{~m}), 1344(\mathrm{w}), 1277(\mathrm{~s}), 1177(\mathrm{w}), 1162$ (w), $1108(\mathrm{~m}), 1023(\mathrm{w})$. ESI MS (pos. mode): $\mathrm{m} / \mathrm{z}: 571.1$ $\left(\left[\mathrm{RuCl}_{2}(p \text {-cym })(\mathbf{B})+\mathrm{Na}\right]^{+}\right)$.

Crystals of 2 were obtained from a saturated solution of 2 in methanol by slow evaporation of solvent at room temperature in air over $1 \mathrm{~d}$.

[RuCl $2(p$-cym)(C)] (3). Yield: $150 \mathrm{mg}$ (72\%); orange solid; soluble in DMSO, DMF; moderately soluble in methanol; insoluble in diethyl ether, $n$-hexane. M.p. $199{ }^{\circ} \mathrm{C}$ (decomp., orange to black). Elem. Anal. (found (calcd), \%): 
$\mathrm{C}_{22} \mathrm{H}_{24} \mathrm{Cl}_{2} \mathrm{~N}_{2} \mathrm{O}_{2} \mathrm{Ru}$ (520.42), C 49.40 (50.78), H 5.00 (5.09), $\mathrm{N} 4.53$ (5.23). ${ }^{1} \mathrm{H}$ NMR (300 MHz, DMSO-d 6 ): $\delta 1.21\left(\mathrm{~d},{ }^{3} J_{\mathrm{H}, \mathrm{H}}=\right.$ $\left.6.5 \mathrm{~Hz}, 6 \mathrm{H}, \mathrm{CH}_{3}{ }^{\mathrm{c}}\right), 2.11\left(\mathrm{~s}, 3 \mathrm{H}, \mathrm{CH}_{3}{ }^{\mathrm{b}}\right), 2.85\left(\mathrm{p},{ }^{3} J_{\mathrm{H}, \mathrm{H}}=6.9 \mathrm{~Hz}\right.$, $\left.1 \mathrm{H}, \mathrm{C} H^{\mathrm{d}}\right), 5.81\left(\mathrm{~m}, 4 \mathrm{H}, \mathrm{C} H^{\mathrm{f}}, \mathrm{C} H^{\mathrm{g}}\right), 6.85$ ('t', $\left.1 \mathrm{H}, \mathrm{CH} H^{\mathrm{l}}\right), 6.94$ ('d', $\left.1 \mathrm{H}, \mathrm{C} H^{\mathrm{k}}\right), 7.64\left(\mathrm{t}\right.$ ', $\left.1 \mathrm{H}, \mathrm{C} H^{\mathrm{p}}\right), 7.84\left(\mathrm{~m}, 4 \mathrm{H}, \mathrm{C} H^{\mathrm{m}}, \mathrm{C} H^{\mathrm{o}}\right), 8.24(\mathrm{~s}$, br, $\left.1 \mathrm{H}, \mathrm{CH}^{\mathrm{r}}\right), 9.51(\mathrm{~s}, 1 \mathrm{H}, \mathrm{NH}), 12(\mathrm{~s}, \mathrm{br}, \mathrm{OH}) .{ }^{13} \mathrm{C}\left\{{ }^{1} \mathrm{H}\right\} \mathrm{NMR}$ (75 MHz, DMSO-d ${ }_{6}$ ): $\delta 17.8\left(\mathrm{~s}, C_{3}{ }^{\mathrm{b}}\right), 21.5\left(\mathrm{~s}, C \mathrm{H}_{3}{ }^{\mathrm{c}}\right), 29.9(\mathrm{~s}$, $\left.C \mathrm{H}^{\mathrm{d}}\right), 85.8\left(\mathrm{~s}, C \mathrm{H}^{\mathrm{f}}\right) 86.3\left(\mathrm{~s}, C \mathrm{H}^{\mathrm{g}}\right), 100.1\left(\mathrm{~s}, C^{\mathrm{h}}\right), 106.4\left(\mathrm{~s}, C^{\mathrm{j}}\right)$, $111.7\left(\mathrm{~s}, C \mathrm{H}^{\mathrm{k}}\right), 115.4\left(\mathrm{~s}, C \mathrm{H}^{\mathrm{l}}\right), 116.5\left(\mathrm{~s}, C \mathrm{H}^{\mathrm{m}}\right), 121.6\left(\mathrm{~s}, C^{\mathrm{n}}\right)$, $130.4\left(\mathrm{~s}, C \mathrm{H}^{\mathrm{o}}\right), 137.5\left(\mathrm{~s}, C \mathrm{H}^{\mathrm{P}}\right), 145.9\left(\mathrm{~s}, C^{q}\right), 147.2\left(\mathrm{~s}, C \mathrm{H}^{\mathrm{r}}\right)$, $155.1\left(\mathrm{~s}, C^{S}\right), 167.2$ (s, CO). IR: $\tilde{\nu}\left(\mathrm{cm}^{-1}\right) 3420$ (s, br), 2962 (s), $2380(\mathrm{w}), 2370(\mathrm{w}), 1868(\mathrm{w}), 1844(\mathrm{w}), 1772(\mathrm{w}), 1716(\mathrm{~s})$, 1698 (s), 1683 (s), 1652 (s), 1635 (s), 1602 (s), 1522 (s), 1507 (s), 1457 (s), 1387 (m), 1338 (m), 1261 (s), 1175 (s), 1103 (s). ESI MS (pos. mode): $m / z: 483.1\left([\operatorname{RuCl}(p \text {-cym })(\mathbf{C}-2 \mathbf{H})]^{+}\right)$.

Crystals of 3 were obtained from a saturated solution of 3 in chloroform by slow evaporation of solvent at room temperature in air.

Synthesis of $[\operatorname{RuCl}(p$-cym $)\{\mathrm{D}(\mathrm{Me})\}] \mathrm{PF}_{6}(4)$ and $[\operatorname{RuCl}(p$-cym)(E) $] \mathbf{P F}_{\mathbf{6}}$ (5). $\left[\left\{\mathrm{RuCl}_{2}(p \text {-cym }\}_{2}\right](120 \mathrm{mg}, 0.2 \mathrm{mmol})\right.$ and ligand D. $\mathrm{HCl}(80 \mathrm{mg}, 0.4 \mathrm{mmol})$ or $\mathbf{E} \cdot \mathrm{HCl}(106 \mathrm{mg}, 0.4 \mathrm{mmol})$ were dissolved in methanol $(15 \mathrm{ml})$. The clear, deep red solution was heated to reflux for $4 \mathrm{~h}$, and then cooled to room temperature and stirred for another $12 \mathrm{~h} . \mathrm{NH}_{4} \mathrm{PF}_{6}(66 \mathrm{mg}, 0.4 \mathrm{mmol})$ was added as a solid and the solution was heated at reflux for another $2 \mathrm{~h}$. The solvent was reduced to $10 \mathrm{ml}$ and layered with diethyl ether $(60 \mathrm{ml})$ to precipitate the reddish yellow crude product. The product (4 or 5 ) was filtered off and washed with acetone $(40 \mathrm{ml})$. The filtrate of 5 was reduced to $5 \mathrm{ml}$ and layered with diethyl ether $(40 \mathrm{ml})$ to yield compound 6. All solids were dried in air.

$[\operatorname{RuCl}(\boldsymbol{p}$-cym $)\{\mathbf{D}(\mathbf{M e})\}] \mathbf{P F}_{6}$ (4). Yield: $80 \mathrm{mg}$ (33\%); microcrystalline Indian yellow solid; soluble in acetone, methanol, DMSO, DMF; moderately soluble in water, insoluble in $n$-hexane, diethyl ether. M.p. $185{ }^{\circ} \mathrm{C}$ (decomp., Indian yellow to black). Elem. Anal. (found (calcd), \%): $\mathrm{C}_{19} \mathrm{H}_{26} \mathrm{ClN}_{2} \mathrm{O}_{2} \mathrm{RuPF}_{6}$ (595.91), C 38.01 (38.30), 4.35 (4.40), N 4.67 (4.70). ${ }^{1} \mathrm{H}$ NMR (400 MHz, DMSO-d $\left.\mathrm{d}_{6}\right): \delta 1.10-1.15\left(\mathrm{~m}, 6 \mathrm{H}, \mathrm{CH}_{3}{ }^{\mathrm{a}}\right), 2.01(\mathrm{~s}, 3 \mathrm{H}$, $\left.\mathrm{CH}_{3}{ }^{\mathrm{b}}\right), 2.80\left(\mathrm{p},{ }^{3} J_{\mathrm{H}, \mathrm{H}}=6.9 \mathrm{~Hz}, 1 \mathrm{H}, \mathrm{CH}^{\mathrm{c}}\right), 3.73\left(\mathrm{~s}, 3 \mathrm{H}, \mathrm{C} H^{\mathrm{d}}\right)$, 3.75-3.88 (m, 1H, CH $\left.H^{\mathrm{e}}\right), 4.03-4.07\left(\mathrm{~m}, 1 \mathrm{H}, \mathrm{C} H^{\mathrm{e}}\right), 4.30-4.33(\mathrm{~m}$, $\left.1 \mathrm{H}, \mathrm{C} H^{\mathrm{f}}\right), 4.45-4.58\left(\mathrm{~m}, 1 \mathrm{H}, \mathrm{C} H^{\mathrm{f}}\right), 5.78\left(\mathrm{~d},{ }^{3} J_{\mathrm{H}, \mathrm{H}}=6.1 \mathrm{~Hz}, 1 \mathrm{H}\right.$, $\left.\mathrm{CH}^{\mathrm{g}}\right), 5.82\left(\mathrm{~d},{ }^{3} J_{\mathrm{H}, \mathrm{H}}=6.1 \mathrm{~Hz}, 1 \mathrm{H}, \mathrm{C} H^{\mathrm{g}}\right), 5.94\left(\mathrm{~d},{ }^{3} J_{\mathrm{H}, \mathrm{H}}=6.1 \mathrm{~Hz}\right.$, $\left.1 \mathrm{H}, \mathrm{CH}^{\mathrm{g}}\right), 5.96\left(\mathrm{~d},{ }^{3} J_{\mathrm{H}, \mathrm{H}}=6.1 \mathrm{~Hz}, 1 \mathrm{H}, \mathrm{CH}^{\mathrm{g}}\right), 7.52-7.56(\mathrm{~m}, 2 \mathrm{H}$, $\left.\mathrm{CH}^{\mathrm{h}} \mathrm{C} H^{\mathrm{j}}\right), 7.99\left(\right.$ 't', $\left.1 \mathrm{H}, \mathrm{CH}^{\mathrm{k}}\right), 9.20\left(\right.$ 'd', $\left.1 \mathrm{H}, \mathrm{CH}^{\mathrm{l}}\right) ; \mathrm{NH}$ overlaid by other signals. ${ }^{13} \mathrm{C}\left\{{ }^{1} \mathrm{H}\right\}$ NMR (100 MHz, DMSO-d ${ }_{6}$ ): $\delta 17.5$ (s, $\left.\mathrm{CH}_{3}{ }^{\mathrm{b}}\right), 21.4\left(\mathrm{~s}, \mathrm{CH}_{3}{ }^{\mathrm{a}}\right), 22.8\left(\mathrm{~s}, \mathrm{CH}_{3}{ }^{\mathrm{a}}\right), 30.7\left(\mathrm{~s}, C \mathrm{H}^{\mathrm{c}}\right), 52.5\left(\mathrm{~s}, \mathrm{CH}_{3}{ }^{\mathrm{d}}\right)$, $55.8\left(\mathrm{~s}, C \mathrm{H}^{\mathrm{e}}\right), 57.8\left(\mathrm{~s}, C \mathrm{H}^{\mathrm{f}}\right), 82.8\left(\mathrm{~s}, C \mathrm{H}^{\mathrm{g}}\right), 82.9\left(\mathrm{~s}, C \mathrm{H}^{\mathrm{g}}\right), 83.9(\mathrm{~s}$, $\left.C \mathrm{H}^{\mathrm{g}}\right), 85.8\left(\mathrm{~s}, C \mathrm{H}^{\mathrm{g}}\right), 122.1\left(\mathrm{~s}, C \mathrm{H}^{\mathrm{h}}\right), 125.5\left(\mathrm{~s}, C \mathrm{H}^{\mathrm{j}}\right), 140.0\left(\mathrm{~s}, C \mathrm{H}^{\mathrm{k}}\right)$, $155.0\left(\mathrm{~s}, C \mathrm{H}^{\mathrm{l}}\right), 161.2\left(\mathrm{~s}, C^{\mathrm{m}}\right), 169.5(C \mathrm{O}) . \mathrm{IR}: \tilde{\nu}\left(\mathrm{cm}^{-1}\right) 3418(\mathrm{br}, \mathrm{s})$, 3270 (s), 2960 (s), 1757 (s), 1736 (m), 1615 (m), 1432 (m), 1389 (m), 1360 (m), 1285 (m), 1237 (s), 1200 (s), 1095 (m), 1027 (m), 835 (s). ESI MS (pos. mode): $m / z: 451.1$ ([RuCl $\left.(p-c y m)(D M e)]^{+}\right)$.

Crystals of $\mathbf{4}$ were obtained from a solution of $\mathbf{4}$ in methanol by slow evaporation of solvent at room temperature in air.

$[\operatorname{RuCl}(p$-cym $)(\mathrm{E})] \mathrm{PF}_{6}(5)$ and $[\operatorname{RuCl}(p$-cym $)(\mathrm{E}-2 \mathrm{H})] \mathrm{PF}_{6}(6) . \mathrm{A}$ few orange crystals of $\mathbf{5}$ were obtained from the reaction mixture (solvent methanol) in inert atmosphere at $-4{ }^{\circ} \mathrm{C}$ after $48 \mathrm{~h}$, but were shown to have the composition [RuCl$(p$-cym $)(\mathbf{E})]_{2}\left[\mathrm{Ru}_{2} \mathrm{Cl}_{3}(p \text {-cym })_{2}\right]\left[\mathrm{PF}_{6}\right]_{3} \cdot 1 \mathrm{MeOH} \quad\left(5^{+} \mathbf{I}^{+}\left[\mathrm{PF}_{6}\right]_{3} \cdot 1 \mathrm{MeOH}\right)$. Complex $\mathbf{5}$ is unstable in air and in aqueous solution and is converted to complex $\mathbf{6}$ after filtration and washing with acetone in air (Scheme 1). Crystals of 6 were obtained from methanol as red needles after slow evaporation of solvent in air. Only complex 6 was further characterised. Yield: $60 \mathrm{mg}$ (25\%); microcrystalline orange solid; soluble in acetone, methanol, DMSO, DMF; poorly soluble in water; insoluble in $n$-hexane, diethyl ether. M.p. $=200{ }^{\circ} \mathrm{C}$ (decomp., orange to black). Elem. Anal. (found (calcd), \%): $\mathrm{C}_{23} \mathrm{H}_{24} \mathrm{ClN}_{2} \mathrm{O}_{2} \mathrm{RuPF}_{6}$ (641.94), C 41.97 (43.03), H 3.41 (3.77), 4.75 (4.36). ${ }^{1} \mathrm{H}$ NMR $\left(400 \mathrm{MHz}, \mathrm{DMSO}-\mathrm{d}_{6}\right): \delta 0.99\left(\mathrm{~d},{ }^{3} J_{\mathrm{H}, \mathrm{H}}=6.4 \mathrm{~Hz}, 6 \mathrm{H}, \mathrm{CH}_{3}{ }^{\mathrm{a}}\right), 2.17$ $\left(\mathrm{s}, 3 \mathrm{H}, \mathrm{CH}_{3}{ }^{\mathrm{b}}\right), 2.53\left(\mathrm{p},{ }^{3} J_{\mathrm{H}, \mathrm{H}}=6.7 \mathrm{~Hz}, 1 \mathrm{H}, \mathrm{C} H^{\mathrm{c}}\right), 5.61\left(\mathrm{~d},{ }^{3} J_{\mathrm{H}, \mathrm{H}}=\right.$ $\left.6.1 \mathrm{~Hz}, 1 \mathrm{H}, \mathrm{C} H^{\mathrm{d}}\right), 5.69\left(\mathrm{~d},{ }^{3} J_{\mathrm{H}, \mathrm{H}}=6.1 \mathrm{~Hz}, 1 \mathrm{H}, \mathrm{C} H^{\mathrm{d}}\right), 5.79(\mathrm{~d}$, $\left.{ }^{3} J_{\mathrm{H}, \mathrm{H}}=6.1 \mathrm{~Hz}, 1 \mathrm{H}, \mathrm{C} H^{\mathrm{d}}\right), 6.10\left(\mathrm{~d},{ }^{3} J_{\mathrm{H}, \mathrm{H}}=6.1 \mathrm{~Hz}, 1 \mathrm{H}, \mathrm{C} H^{\mathrm{d}}\right), 7.90$ $\left(\mathrm{m}, 3 \mathrm{H}, \mathrm{C} H^{\mathrm{g}}, \mathrm{C} H^{\mathrm{h}}\right), 8.19\left(\mathrm{~d},{ }^{3} J_{\mathrm{H}, \mathrm{H}}=8.4 \mathrm{~Hz}, 2 \mathrm{H}, \mathrm{C} H^{\mathrm{k}}\right), 8.33(\mathrm{~m}$, $\left.2 \mathrm{H}, \mathrm{C} H^{\mathrm{j}}, \mathrm{C} H^{\mathrm{m}}\right), 9.00\left(\mathrm{~s}, 1 \mathrm{H}, \mathrm{C} H^{\mathrm{q}}\right), 9.60\left(\right.$ 'd', $\left.1 \mathrm{H}, \mathrm{C} H^{\mathrm{P}}\right), 13(\mathrm{~s}, \mathrm{br}$, $1 \mathrm{H}, \mathrm{OH}) .{ }^{13} \mathrm{C}\left\{{ }^{1} \mathrm{H}\right\}$ NMR (100 MHz, DMSO-d 6 ): $\delta 18.3\left(\mathrm{~s}, \mathrm{CH}_{3}{ }^{\mathrm{b}}\right)$, $21.6\left(\mathrm{~s}, \mathrm{CH}_{3}{ }^{\mathrm{a}}\right), 21.7\left(\mathrm{~s}, \mathrm{CH}_{3}{ }^{\mathrm{a}}\right), 30.5\left(\mathrm{~s}, \mathrm{CH}^{\mathrm{c}}\right), 84.9\left(\mathrm{~s}, 2 \times \mathrm{CH}^{\mathrm{d}}\right)$, $86.0\left(\mathrm{~s}, C \mathrm{H}^{\mathrm{d}}\right), 86.7\left(\mathrm{~s}, C \mathrm{H}^{\mathrm{d}}\right), 103.8\left(\mathrm{~s}, C^{\mathrm{e}}\right), 105.3\left(\mathrm{~s}, C^{\mathrm{f}}\right), 122.8(\mathrm{~s}$, $\left.C \mathrm{H}^{\mathrm{g}}\right), 129.2\left(\mathrm{~s}, C \mathrm{H}^{\mathrm{h}}\right), 130.5\left(\mathrm{~s}, C \mathrm{H}^{\mathrm{j}}\right), 130.7\left(\mathrm{~s}, C \mathrm{H}^{\mathrm{k}}\right), 131.7(\mathrm{~s}$, $\left.C^{\mathrm{l}}\right), 140.0\left(\mathrm{~s}, C \mathrm{H}^{\mathrm{m}}\right), 154.4\left(\mathrm{~s}, C^{\mathrm{n}}\right), 154.8\left(\mathrm{~s}, C^{\mathrm{o}}\right), 156.1\left(\mathrm{~s}, C \mathrm{H}^{\mathrm{p}}\right)$, $166.5(C O), 168.9\left(\mathrm{~s}, C \mathrm{H}^{\mathrm{q}}\right)$. IR: $\tilde{\nu}\left(\mathrm{cm}^{-1}\right): 3418(\mathrm{~m}, \mathrm{br}), 2322(\mathrm{w})$, $2929(\mathrm{w}), 1723(\mathrm{~m}), 1708$ (m), 1601 (w), $1475(\mathrm{w}), 1417(\mathrm{w})$, 1105 (w), 839 (s). ESI MS (pos. mode): $m / z: 497.1$ ([RuCl $(p$-cym) $\left.(\mathbf{E}-2 \mathbf{H})]^{+}\right)$.

\section{X-ray data collection and structure refinement}

The data of complexes 2 to 6 were collected at $130 \mathrm{~K}$ on a Gemini diffractometer (Rigaku Corp.) by using Mo-K $\alpha$ radiation $(\lambda=71.073 \mathrm{pm})$ and $\omega$-scan rotation. Data reduction was performed with CrysAlis Pro ${ }^{47}$ including the program SCALE3 ABSPACK for empirical absorption correction. All structures were solved by direct methods, ${ }^{48,49}$ and the refinement of all non-hydrogen atoms was performed with SHELXL-2013 or SHELXL-2014. ${ }^{49}$ Excluding strongly overlapping disordered parts of the structures, all non-hydrogen atoms were refined with anisotropic thermal parameters. A difference-density Fourier map was used to locate all hydrogen atoms of compound 6 and $\mathrm{OH}$ and $\mathrm{NH}$ hydrogen atoms of 3 and 4 . All other $\mathrm{H}$ atoms were calculated on idealised positions by using the riding model. Structure figures were generated with DIAMOND-3. ${ }^{50}$ CCDC 1421200 (2), 1421201 (3), 1421202 (4), 1421203 (5), and 1421204 (6) contain the supplementary crystallographic data for this paper.

\section{DNA binding studies}

Absorption spectra were measured with a Shimadzu 1800 spectrophotometer. The concentration of calf thymus DNA was determined by UV absorbance at $260 \mathrm{~nm}$ by taking the molar absorption coefficient as $6600 \mathrm{M}^{-1} \mathrm{~cm}^{-1}$. Solutions of CT-DNA in phosphate buffer gave a ratio of UV absorbance at 260 and $280 \mathrm{~nm}, A_{260} / A_{280}$, of $1.8-1.9: 1$, indicating that the DNA was sufficiently free of protein. ${ }^{46}$ Absorption titration experiments 
were performed by maintaining a constant metal-complex concentration $(100 \mu \mathrm{M})$ and varying nucleotide concentration $(0-200 \mu \mathrm{M})$ in phosphate buffer $(\mathrm{pH}=7.2)$. After addition of DNA to the metal complex, absorption readings were noted. The emission spectra were measured with a Jasco spectrofluorometer; the excitation slit widths employed were $5 \mathrm{~nm}$ each. The change in emission intensity of metal complex at fixed metal concentration $(100 \mu \mathrm{M})$ with increasing concentration of DNA was measured on excitation at $\lambda_{\max }(260-380 \mathrm{~nm})$.

The mode of binding was also studied by a competitive binding assay with ethidium bromide (EtBr)-bound DNA in phosphate buffer $(\mathrm{pH}=7.2)$. The emission was observed at $580 \mathrm{~nm}$ on excitation at $530 \mathrm{~nm}$. Ethidium bromide in phosphate buffer shows quenched emission intensity, but in the presence of DNA, EtBr shows enhanced emission intensity.

The viscosity measurements were carried out with a SchottGeräte ViscoSystem AVS 370 maintained at $28.0 \pm 1{ }^{\circ} \mathrm{C}$. Flow time of solutions in phosphate buffer $(\mathrm{pH}=7.2)$ was recorded in triplicate for each sample with a digital stop watch, and an average flow time was calculated. Data were presented as $\left(\eta / \eta_{0}\right)^{1 / 3}$ versus binding ratio, where $\eta$ is the viscosity of DNA in the presence of the complex and $\eta_{0}$ is the viscosity of DNA alone.

DNA melting experiments were carried out by monitoring the absorption at $260 \mathrm{~nm}$ of CT-DNA $(100 \mu \mathrm{M})$ with a Jasco V-630 spectrophotometer equipped with a Peltier temperaturecontrolling programmer ETC-717 $\left(0.1^{\circ} \mathrm{C}\right)$ in phosphate buffer at various temperatures in the absence and presence of the complexes $(20 \mu \mathrm{M})$. UV melting profiles were obtained by scanning $A_{260}$ absorbance monitored at a heating rate of $1{ }^{\circ} \mathrm{C}$ $\min ^{-1}$ for solutions of CT-DNA $(100 \mu \mathrm{M})$ in the temperature range $20-90{ }^{\circ} \mathrm{C}$. The melting temperature $T_{\mathrm{m}}$ which is defined as the temperature at which half of the total base pairs are unbound, was determined from the midpoint of the melting curves.

The CD spectra of CT-DNA $(20 \mu \mathrm{M})$ were monitored in absence and presence of metal complex in phosphate buffer by using a Jasco J-1500 spectrophotometer.

\section{DNA cleavage studies}

The electrophoretic mobility experiments were carried out by agarose gel electrophoresis ${ }^{51-53}$ on a $10 \mu$ l total sample volume solution containing $p B R 322$ DNA (200 ng) and the respective ruthenium(II) complex. Stock solutions $(10 \mu \mathrm{M}$ and $20 \mu \mathrm{M})$ of 1-4 and 6 were prepared in 2\% DMSO and water. Supercoiled pBR322 DNA was treated with the complexes $(2-200 \mu \mathrm{M})$ and the mixtures were incubated in the dark for $30 \mathrm{~min}$ at $37^{\circ} \mathrm{C}$. The samples were analysed by $1 \%$ agarose gel electrophoresis [TBE buffer $(\mathrm{TBE}=\mathrm{TRIS} /$ borate/EDTA, TRIS $=$ tris(hydroxymethyl)aminomethane), $\mathrm{pH}=7.8$ ] for $3 \mathrm{~h}$ at $60 \mathrm{~V}$. The gel was stained with a $0.5 \mu \mathrm{g} \mathrm{ml}{ }^{-1}$ ethidium bromide, visualised by UV light and photographed for analysis with an Alpha Innotech Gel documentation system (Alphamager 2200).

\section{Cytotoxicity studies}

Foetal calf serum (FCS), RPMI-1640 medium, phosphatebuffered saline (PBS), dimethylformamide (DMF) and propi- dium iodide (PI) were purchased from Sigma (St. Louis, MO). Annexin V-FITC (AnnV) was purchased from Biotium (Hayward, CA) and Apostat from R\&D (R\&D Systems, Minneapolis, MN USA). Human 518A2, 8505C, MCF-7 and SW-480 were cultivated in HEPES-buffered RPMI-1640 medium supplemented with 10\% FCS, $2 \mathrm{mM}$ L-glutamine, $0.01 \%$ sodium pyruvate and antibiotics (culture medium) at $37{ }^{\circ} \mathrm{C}$ in a humidified atmosphere with $5 \% \mathrm{CO}_{2}$. After standard trypsinisation, cells were seeded at $(1-2) \times 10^{3}$ cells per well in 96-well plates for viability determination and $2 \times 10^{5}$ cells per well in 6-well plates for flow-cytometric analysis. All compounds were dissolved in DMF immediately before treatment and solutions used were prepared in 10\% FCS-RPMI-1640. Controls were exposed to equivalent amounts of DMF in culture medium.

\section{Sulforhodamine B test (SRB test)}

For evaluation of the effect of complexes 1-4, 6 and ligands A-E on the viability of tumour cells, an SRB test was used. ${ }^{54}$ Tumour cells were treated for $96 \mathrm{~h}$ with a wide range of concentrations of these compounds. At the end of cultivation, cells were fixed with $10 \%$ of trichloroacetic acid (TCA) for $2 \mathrm{~h}$ at $4{ }^{\circ} \mathrm{C}$. After fixation, cells were washed with distilled water and additionally stained for $30 \mathrm{~min}$ at room temperature with $0.4 \%$ SRB solution. Then the cells were washed with $1 \%$ acetic acid and dried overnight. The dye was dissolved in $10 \mathrm{mM}$ TRIS buffer, and after 20 min of incubation at room temperature, the absorbance was measured at $540 \mathrm{~nm}$ with the reference wavelength at $670 \mathrm{~nm}$. Results were expressed as percentage of untreated cells (control) and presented as mean \pm standard deviation (SD).

\section{AnnexinV-FITC/PI and caspase detection}

Cells were incubated with a $2 \times \mathrm{IC}_{50}$ dose of a selected complex (2) for $72 \mathrm{~h}$. At the end of cultivation, cells were stained with AnnV-FITC/PI or Apostat according to the manufacturer's instructions. Cells were analysed with CyFlow ${ }^{\circledR}$ Space Partec by using the Partec FloMax® software. ${ }^{55}$

\section{Cell staining with carboxyfluorescein succinimidyl ester (CFSE)}

Before exposure to complex 2, cells were stained with $1 \mu \mathrm{M}$ of CFSE for $10 \mathrm{~min}$ at $37^{\circ} \mathrm{C} .{ }^{56}$ Thereafter, cells were washed and additionally cultivated for $72 \mathrm{~h}$ with an $\mathrm{IC}_{50}$ dose of 2 . Finally, cells were examined with CyFlow ${ }^{\circledR}$ Space Partec using Partec FloMax® software. ${ }^{55}$

\section{Statistical analysis}

Results are presented as mean \pm standard deviation (SD) of triplicate observations obtained from three individually repeated experiments. The significance of the differences between control and treated culture was evaluated by twotailed Student's $t$-test. A $p$ value of less than 0.05 was considered significant. 


\section{Results and discussion}

Synthesis

The ruthenium complex $\left[\left\{\mathrm{RuCl}_{2}(p \text {-cym })\right\}_{2}\right]$ is an excellent starting material for synthesis of novel $\mathrm{Ru}^{\mathrm{II}}$ complexes with monoor bidentate amine or phosphine ligands. ${ }^{57,58}$ Complex 1 was prepared according to a literature procedure and the identity and purity were verified by ${ }^{1} \mathrm{H}$ and ${ }^{13} \mathrm{C}$ NMR spectroscopy; ${ }^{46}$ complexes 2-5 were synthesised accordingly by treating $\left[\left\{\mathrm{RuCl}_{2}(p \text {-cym })\right\}_{2}\right]$ with the corresponding amine ligand B-E under inert atmosphere (Scheme 1). Complexes 2 and 3 form orange solids within several minutes even at room temperature, underlining the reactivity of the ruthenium complex $\left[\left\{\operatorname{RuCl}_{2}(p \text {-cym })\right\}_{2}\right]$ toward Lewis bases such as amines. In air, complex 5 reacts with oxygen with elimination of hydrogen and formation of water to give complex $\mathbf{6}$, which exhibits an imine group. Gomez et al. have described similar ruthenium complexes $[\mathrm{Ru}(p$-cym)(pyridine- $\mathrm{NH}$-arene) $)$ and their oxidation to similar products. ${ }^{59}$ The products were characterised by ${ }^{1} \mathrm{H}$ and ${ }^{13} \mathrm{C}\left\{{ }^{1} \mathrm{H}\right\}$ NMR spectroscopy, IR spectroscopy and ESI MS, and the single-crystal X-ray structures of 2-6 were obtained. The spectroscopic data are as expected..$^{57,58}$

Stock solutions of the compounds in DMSO were stored at $4{ }^{\circ} \mathrm{C}$ to ensure the stabilities of the investigated solutions. Furthermore, the stock solutions were checked by timeresolved UV/VIS measurements before use.

\section{Molecular structures of complexes 2-6}

Single crystals suitable for X-ray structure analysis were obtained for complexes 2-6 (Table SI-1, ESI $\dagger$ ). Complexes 2 and 3 with a monodentate N-donor ligand crystallised from methanol (compound 2) as light red needles in the monoclinic space group $P 21 / c$ (2, Fig. 1a) or from chloroform (compound 3) as red needles in the triclinic space group $P \overline{1}$ with two molecules of chloroform per formula unit $\left(3 \cdot 2 \mathrm{CHCl}_{3}\right.$, Fig. 1b). Selected bond lengths and angles of 2 and 3 are listed in Table 1 . In both complexes the ruthenium atom is coordinated by para-cymene, the monodentate amine ligand $\mathbf{B}$ or $\mathbf{C}$ and two chlorido ligands in a typical distorted piano-stool geometry. The environment of the $\mathrm{Ru}^{\mathrm{II}}$ atom in 2 and $\mathbf{3}$ (Table 1 ) is similar to those previously found in related complexes, ${ }^{57}$ e.g., $\left[\mathrm{RuCl}_{2}\right.$ $(p$-cym)(2-aminopyridine $)] .^{60}$ Furthermore, a hydrogen bond $[\mathrm{Cl} 2 \cdots \mathrm{N} 23.090(4)$ (for 2) and 3.076(3) $\AA$ (for 3)] between the
Table 1 Selected bond lengths ( $(\AA)$ and angles $\left(^{\circ}\right)$ in 2 and 3 (Cen is centre of the $p$-cym ligand)

\begin{tabular}{|c|c|c|}
\hline & 2 & 3 \\
\hline $\mathrm{Ru}-\mathrm{N} 1$ & $2.172(3)$ & $2.168(4)$ \\
\hline $\mathrm{Ru}-\mathrm{N} 2$ & $3.231(3)$ & $3.234(4)$ \\
\hline $\mathrm{Ru}-\mathrm{Cl} 1$ & $2.4343(8)$ & $2.407(1)$ \\
\hline $\mathrm{Ru}-\mathrm{Cl} 2$ & $2.4059(9)$ & $2.440(1)$ \\
\hline $\mathrm{Ru}-\mathrm{C} 1$ & $2.198(5)$ & $2.195(3)$ \\
\hline $\mathrm{Ru}-\mathrm{C} 2$ & $2.169(5)$ & $2.183(3)$ \\
\hline $\mathrm{Ru}-\mathrm{C} 3$ & $2.178(5)$ & $2.181(3)$ \\
\hline $\mathrm{Ru}-\mathrm{C} 4$ & $2.197(5)$ & $2.197(4)$ \\
\hline $\mathrm{Ru}-\mathrm{C} 5$ & $2.176(5)$ & $2.167(3)$ \\
\hline $\mathrm{Ru}-\mathrm{C} 6$ & $2.175(5)$ & $2.154(3)$ \\
\hline $\mathrm{Ru}-\operatorname{Cen}(p-\mathrm{cym})$ & $1.6626(4)$ & $1.6606(3)$ \\
\hline $\mathrm{Cl} 2 \cdots \mathrm{N} 2$ & $3.090(4)$ & $3.075(3)$ \\
\hline $\mathrm{O} 1 \cdots \mathrm{O} 2^{\prime}$ & - & $2.599(4)$ \\
\hline $\mathrm{Cl} 1-\mathrm{Ru}-\mathrm{Cl} 2$ & $85.46(4)$ & $85.46(4)$ \\
\hline Cl1-Ru-N1 & $88.7(1)$ & $86.41(8)$ \\
\hline $\mathrm{Cl} 2-\mathrm{Ru}-\mathrm{N} 1$ & $89.2(1)$ & $90.02(8)$ \\
\hline $\mathrm{N} 1-\mathrm{Ru}-\mathrm{Cen}(p$-cym $)$ & $125.6(1)$ & $125.54(8)$ \\
\hline $\mathrm{Cl} 2-\mathrm{Ru}-\mathrm{Cen}(p-\mathrm{cym})$ & $127.23(3)$ & $127.81(3)$ \\
\hline $\operatorname{Cl} 1-\mathrm{Ru}-\mathrm{Cen}(p$-cym $)$ & $127.65(3)$ & $128.27(3)$ \\
\hline $\mathrm{N} 1-\mathrm{C} 15-\mathrm{N} 2$ & $115.6(4)$ & $115.6(3)$ \\
\hline $\mathrm{Ru}-\mathrm{N} 1-\mathrm{C} 11$ & $117.6(3)$ & $123.4(3)$ \\
\hline $\mathrm{Ru}-\mathrm{N} 1-\mathrm{C} 15$ & $117.1(2)$ & $123.9(2)$ \\
\hline
\end{tabular}

chlorido ligand and the $\mathrm{NH}$ proton is observed. ${ }^{60}$ In 3 , centrosymmetric dimers are formed by moderately strong hydrogen

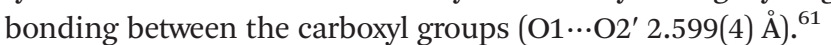

Complexes 4, 5 and 6 with a bidentate N-donor ligand crystallised from methanol (Table SI-1, ESI $\dagger$ ). [RuCl( $p$-cym)$\{\mathbf{D}(\mathrm{Me})\}] \mathrm{PF}_{6}$ (4) crystallised as dark-red needles in the orthorhombic space group $\mathrm{Pna2}_{1}$. Esterification had occurred in refluxing methanol (Fig. 2a, Table 2). An intramolecular hydrogen bond ( $\mathrm{Cl} 1 \cdots \mathrm{H}$ 2.0(1) $\AA$ ) between the chlorido ligand and the $\mathrm{NH}$ proton is observed. ${ }^{60}$ Unexpectedly, orange crystals obtained on recrystallising $\mathbf{5}$ from methanol in inert atmosphere at $-4{ }^{\circ} \mathrm{C}$ after $48 \mathrm{~h}$ contained two different cations: two pseudo-symmetry-related cations of the target compound $[\operatorname{RuCl}(p \text {-cym })(\mathbf{E})]^{+}\left(5^{+}\right)$(Fig. $\left.2 \mathrm{~b}\right)$ with hydrogen bonds between

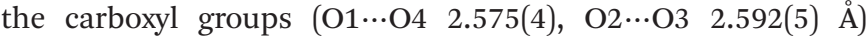
(Table 2), and the dinuclear complex $\left[\mathrm{Ru}_{2} \mathrm{Cl}_{3}(p \text {-cym })_{2}\right]^{+}\left(\mathbf{I}^{+}\right)$. $\left[\mathrm{Ru}_{2} \mathrm{Cl}_{3}(p \text {-cym })_{2}\right]^{+}\left(\mathbf{I}^{+}\right)$is located on a crystallographic inversion centre with disordered chlorine atoms. The cation was described previously. ${ }^{43,62}$ The compound crystallises in the monoclinic space group $P 2_{1} / c$ as $[\operatorname{RuCl}(p \text {-cym })(\mathbf{E})]_{2}\left[\mathrm{Ru}_{2} \mathrm{Cl}_{3^{-}}\right.$ a)

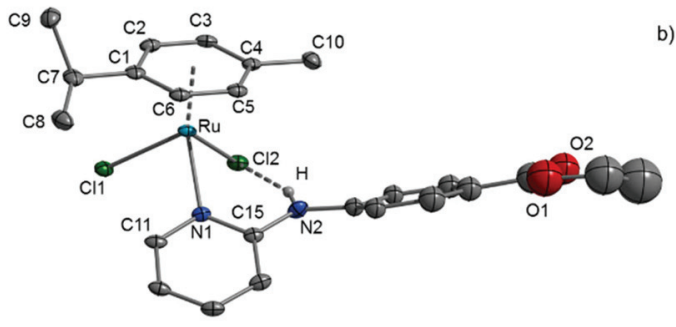

b)

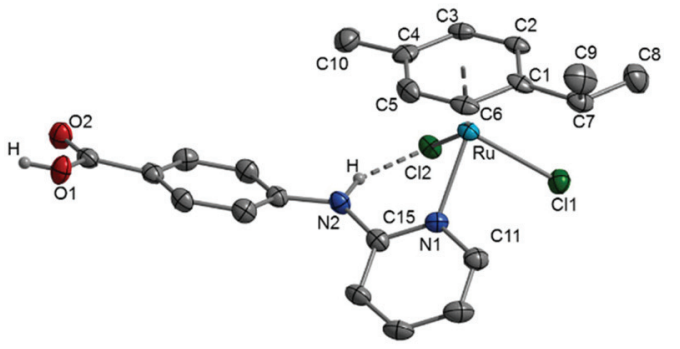

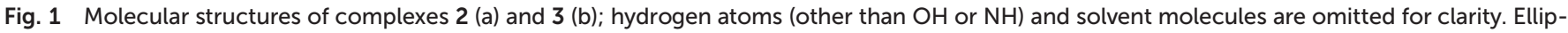
soids are drawn at $30 \%$ probability. The benzoic acid moiety in 2 is disordered. 
a)

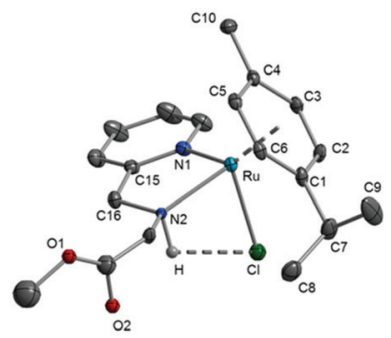

b)

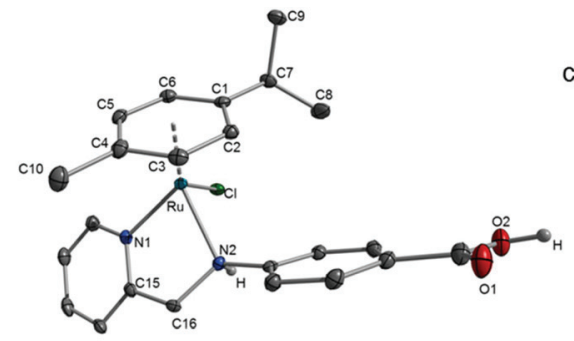

c)

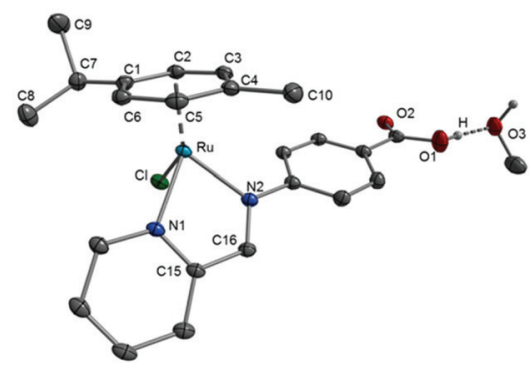

Fig. 2 Molecular structures of complexes $4^{+}$(a) (only the $R_{\mathrm{Ru}}, R_{\mathrm{N}}$ isomer is shown), $5^{+}$(b) (only the $R_{\mathrm{Ru}}, R_{\mathrm{N} 2}$ isomer is shown; $\left[\mathrm{Ru}_{2} \mathrm{Cl}_{3}(p-\mathrm{cym})_{2}\right]^{+}\left(\mathrm{I}^{+}\right)$ not shown) and $6^{+}$(c) (only the $R_{\mathrm{Ru}}$ isomer is shown); hydrogen atoms (other than $\mathrm{NH}$ or $\mathrm{OH}$ ), $\mathrm{PF}_{6}{ }^{-}$anions and $\mathrm{MeOH}$ in (b) are omitted for clarity. Ellipsoids are drawn at $30 \%$ probability.

Table 2 Selected bond lengths ( $(\AA)$ and angles $\left(^{\circ}\right)$ in 4-6 (Cen is the centre of the $p$-cym ligand; values for the second pseudo-symmetryrelated cation of 5 are given in brackets)

\begin{tabular}{llll}
\hline & $\mathbf{4}$ & $\mathbf{5}$ & $\mathbf{6}$ \\
\hline $\mathrm{Ru}-\mathrm{N} 1$ & $2.094(3)$ & $2.102(3)[2.088(3)]$ & $2.082(1)$ \\
$\mathrm{Ru}-\mathrm{N} 2$ & $2.12(2)$ & $2.156(3)[2.154(3)]$ & $2.089(2)$ \\
$\mathrm{Ru}-\mathrm{Cl}$ & $2.51(1)$ & $2.404(1)[2.407(1)]$ & $2.3939(5)$ \\
$\mathrm{Ru}-\mathrm{C} 1$ & $2.224(4)$ & $2.235(4)[2.224(4)]$ & $2.215(2)$ \\
$\mathrm{Ru}-\mathrm{C} 2$ & $2.199(4)$ & $2.192(4)[2.203(4)]$ & $2.196(2)$ \\
$\mathrm{Ru}-\mathrm{C} 3$ & $2.200(4)$ & $2.191(4)[2.184(4)]$ & $2.210(2)$ \\
$\mathrm{Ru}-\mathrm{C} 4$ & $2.204(4)$ & $2.199(4)[2.194(4)]$ & $2.202(2)$ \\
$\mathrm{Ru}-\mathrm{C} 5$ & $2.171(4)$ & $2.181(4)[2.177(4)]$ & $2.179(2)$ \\
$\mathrm{Ru}-\mathrm{C6}$ & $2.193(4)$ & $2.191(4)[2.186(4)]$ & $2.193(2)$ \\
$\mathrm{Ru}-\mathrm{Cen}(p-c y m)$ & $1.6831(3)$ & $1.6856(4)[1.677(4)]$ & $1.6841(3)$ \\
$\mathrm{C} 16-\mathrm{N} 2$ & $1.52(2)$ & $1.478(5)[1.496(5)]$ & $1.290(2)$ \\
$\mathrm{H} \cdots \mathrm{Cl}$ & $2.0(1)$ & - & - \\
$\mathrm{O} 1 \cdots \mathrm{O} 4$ & - & $2.575(4)[2.592(5)]$ & - \\
$\mathrm{O} 1 \cdots \mathrm{O} 3$ & - & - & $2.618(3)$ \\
$\mathrm{N} 1-\mathrm{Ru}-\mathrm{N} 2$ & $79.9(4)$ & $75.3(1)[75.7(1)]$ & $76.92(6)$ \\
$\mathrm{N} 1-\mathrm{Ru}-\mathrm{Cl}$ & $86.1(2)$ & $85.6(1)[85.1(1)]$ & $85.68(4)$ \\
$\mathrm{N} 2-\mathrm{Ru}-\mathrm{Cl}$ & $79.9(6)$ & $82.29(9)[83.76(9)]$ & $85.48(4)$ \\
$\mathrm{Cl}-\mathrm{Ru}-\mathrm{Cen}(p-\mathrm{cym})$ & $120.3(2)$ & $128.11(3)[128.72(3)]$ & $127.53(2)$ \\
$\mathrm{N} 1-\mathrm{Ru}-\mathrm{Cen}(p$-cym) & $132.82(8)$ & $131.82(9)[131.74(1)]$ & $131.18(4)$ \\
$\mathrm{N} 2-\mathrm{Ru}-\mathrm{Cen}(p$-cym) & $138.5(5)$ & $133.31(9)[133.73(9)]$ & $132.17(4)$ \\
& & &
\end{tabular}

$\left.(p \text {-cym })_{2}\right]\left[\mathrm{PF}_{6}\right]_{3} \cdot 1 \mathrm{MeOH}\left(\mathbf{5}^{+} \mathbf{I}^{+}\left[\mathrm{PF}_{6}\right]_{3} \cdot 1 \mathrm{MeOH}\right)$ with four formula units in the unit cell. The dimers of the cation $[\operatorname{RuCl}(p \text {-cym })(\mathbf{E})]^{+}$ $\left(5^{+}\right)$are located on a non-crystallographic centre of inversion. For this compound, pseudo-translation symmetry of $a / 2$ is detectable with the exception of the non-disordered $\mathrm{PF}_{6}{ }^{-}$ anion $[\mathrm{P}(1), \mathrm{F}(1)$ to $\mathrm{F}(6)]$ and the methanol molecule $[\mathrm{C}(67)$ and $\mathrm{O}(5)]$. An originally determined smaller $a$ axis led to unacceptable structure parameters and a wrong stoichiometry because of an overlap of the hidden methanol molecule with a $\mathrm{PF}_{6}{ }^{-}$anion. By considering relatively weak reflections, the correct $a$ axis could be determined.

Complex 6 crystallised from methanol in air as red needles in the monoclinic space group $P 2_{1} / n$ with one molecule of methanol per formula unit. In contrast to $5^{+}$, no dimers are formed via carboxyl groups; here, the carboxyl group interacts

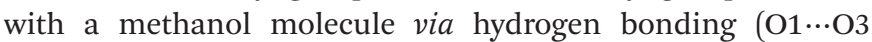
2.618(2) ̊) (Fig. 2c, Table 2).

Complexes $\mathbf{4}^{+}, \mathbf{5}^{+}$and $\mathbf{6}^{+}$(Fig. 2) exhibit the typical distorted tetrahedral three-legged piano-stool geometry with $\eta^{6}$-co- ordinated $p$-cymene, the chelating amine $\mathbf{D}(\mathrm{Me})\left(4^{+}\right), \mathbf{E}\left(5^{+}\right)$or E-2H $\left(6^{+}\right)$and one chlorido ligand. Bond lengths and angles at $\mathrm{Ru}^{\mathrm{II}}$ in $\mathbf{4}^{+}-6^{+}$are very similar. Complexes $4^{+}$and $5^{+}$have two chiral centres ( $\mathrm{Ru}$ and $\mathrm{N} 2)$. In the examined crystals, only the rac isomers are present $\left(R_{\mathrm{Ru}}, R_{\mathrm{N}}\right.$ or $\left.S_{\mathrm{Ru}}, S_{\mathrm{N}}\right)$. Complex $6^{+}$has only one chiral centre (Ru; $R_{\mathrm{Ru}}$ or $\left.S_{\mathrm{Ru}}\right)$. In the air-sensitive dimeric cationic complex $5^{+}$, the five-membered rings exhibit $\mathrm{C}-\mathrm{N}$ bond lengths of 1.478(5) $\AA(\mathrm{C} 16-\mathrm{N} 2)$ and 1.496(5) $\AA$ (C39-N4), which are in the typical range of a C-N single bond, whereas the C16-N2 bond length in $\mathbf{6}^{+}$of 1.290(2) $\AA$ is indicative of a double bond. Chow et al. reported a comparable $\mathrm{Ru}^{\mathrm{II}}$ complex with a $\mathrm{C}=\mathrm{N}$ double bond of $1.293(6) \AA^{.63}$

\section{Biological investigations}

DNA binding studies. Complex 5 is unstable in air and in aqueous solution; therefore, DNA binding, cleavage and cytotoxicity studies were only performed with complexes 1-4 and $\mathbf{6}$.

Electronic absorption spectroscopy is one of the most useful techniques for studying DNA binding by metal complexes. Intercalation of a complex in DNA results in hypochromism and a redshift, ${ }^{64}$ while for non-intercalative binding (covalent, electrostatic and hydrogen bonding) no hypochromism or redshift is observed. The absorption spectra of complexes 1-4 and $\mathbf{6}$ in the absence and presence of CT-DNA show negligible change (Fig. SI-1†) suggesting non-intercalative binding.

Competitive binding studies with ethidium bromide (EtBr)bound DNA were performed to further elucidate the binding nature of complexes 1-4 and 6. Binding of a second molecule to DNA by stacking interactions between adjacent DNA base pairs displaces the ethidium bromide and enhances the emission intensity. However, with complexes 1-4 and 6, no enhancement in the emission intensity is observed, indicating non-intercalative binding (Fig. SI-2†).

CT-DNA melts at $58.00 \pm 1{ }^{\circ} \mathrm{C}$ (phosphate buffer, $\mathrm{pH}=7.2$ ) in the absence of complex. The melting temperature of DNA increased by up to $3{ }^{\circ} \mathrm{C}$ on interaction with complexes 1-4 and 6, which also indicates non-intercalative binding (Table SI-2†).

Hydrodynamic measurements are sensitive to changes in length of DNA and considered to be the most critical and least ambiguous tests for evaluating binding modes in solution. 


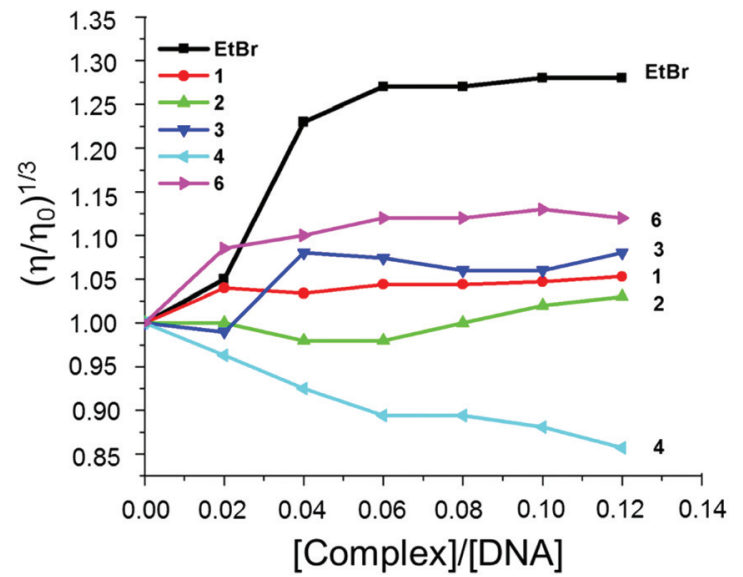

Fig. 3 Effect of increasing amount of $\operatorname{EtBr}(\square), 1(0), 2(\Lambda), 3(\Delta), 4(\Lambda)$ $6(\Lambda)$ on the relative viscosity of CT-DNA at $28 \pm 1{ }^{\circ} \mathrm{C}$, [DNA] $=300 \mu \mathrm{M}$.

The relative specific viscosities of DNA in the absence and presence of complexes 1-4 and $\mathbf{6}$ plotted against [complex]/ [DNA] are shown in (Fig. 3). The relative viscosities of CT-DNA bound complexes increased negligibly, in contrast to the known intercalator ethidium bromide, and this suggests covalent binding of complexes 1-4 and $\mathbf{6}$ with CT-DNA.

Circular dichroism (CD) spectroscopy was used to monitor the conformational change of CT-DNA on addition of complexes 1-4 and 6. There was no change in the CD spectrum of CT-DNA $(20 \mu \mathrm{M})$ on addition of complexes 1-4 and 6 , while a drastic change in the $\mathrm{CD}$ spectrum occurred when a known intercalator, namely, $\left[\mathrm{Ru}(\mathrm{bpy})_{2}(\mathrm{dppz})\right]^{2+},{ }^{65}$ was added (Fig. 4 and SI-3, ESI $\dagger$ ) confirming the non-intercalative and, probably, covalent binding of these complexes, which was investigated further by electrophoretic mobility studies.

Electrophoretic mobility studies. The interaction of 1-4 and 6 with plasmid pBR322 DNA was monitored by agarose gel electrophoresis. Each complex was incubated in the dark at different concentrations with $p B R 322$ DNA at $37^{\circ} \mathrm{C}$. Increasing concentrations of 1 first retarded the mobility of DNA and then increased its mobility through the gel (Fig. 5). The supercoiled DNA (form I) moves rapidly through the gel due to its compact nature, whereas nicked circular (form II) DNA moves slowly, and a closed circular DNA with no net supercoils co-migrates with nicked circular DNA. As the concentration of complex 1 increases, the number of negative supercoils is reduced, leading to slower mobility. Further increase in the complex concentration leaves no supercoils and the closed circular DNA thus formed co-migrates with the nicked circular form. Increasing the complex concentration even further leads to a positive supercoiling of DNA and increased mobility. These interesting alterations in the mobility of DNA occur because the negatively supercoiled helix unwinds first to an open, untwisted form and then transforms into a positively supercoiled form. The retardation of the supercoiled form indicates the capacity of 1-3 to form adducts with DNA leading to local unwinding, similar to cisplatin. It is also note-
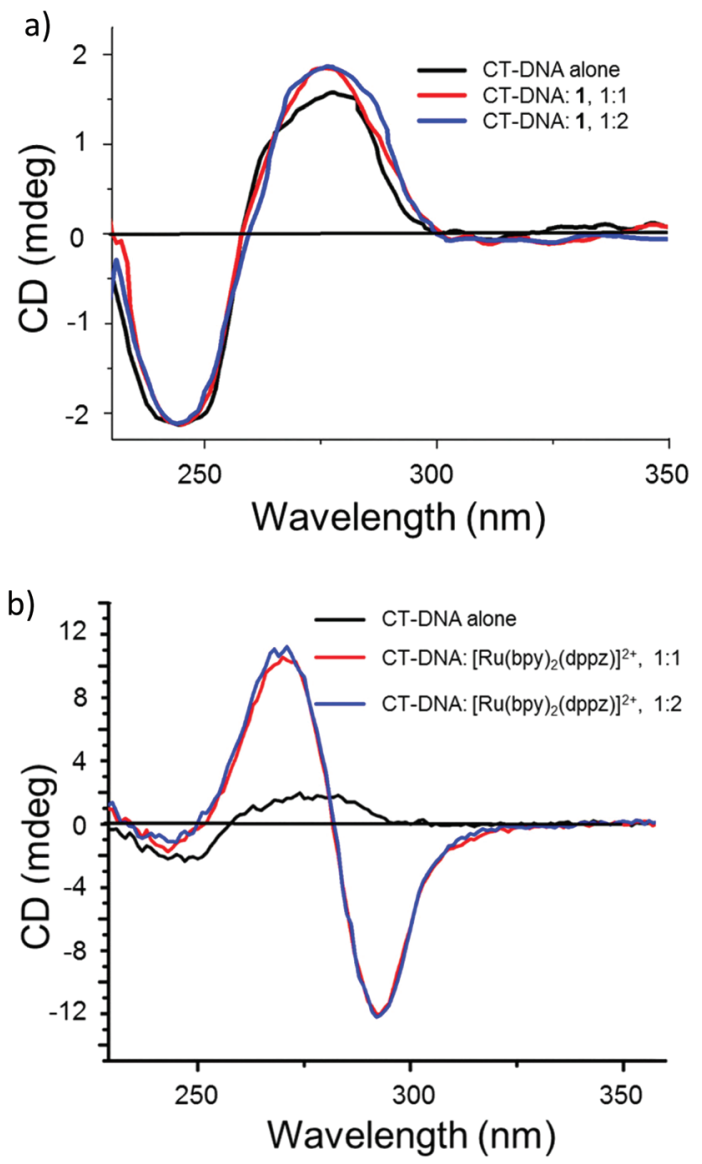

Fig. 4 CD spectra of CT-DNA in the absence and presence of (a) 1 and (b) $\left[\mathrm{Ru}(\mathrm{bpy})_{2}(\mathrm{dppz})\right]^{2+}$ in $10 \mathrm{mM}$ phosphate buffer, $\mathrm{pH}=7.2$, [DNA] = $20 \mu \mathrm{M}$.

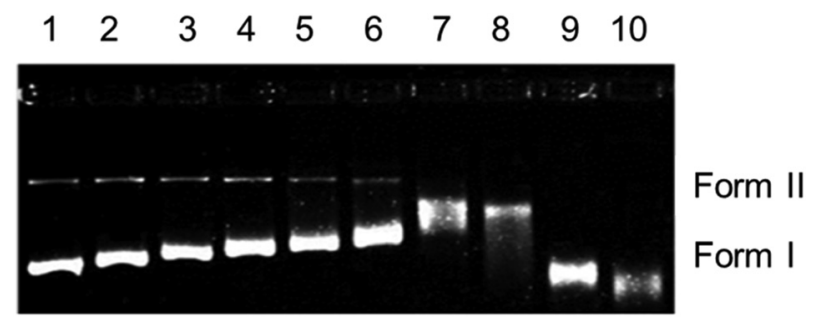

Fig. 5 Agarose (1\%) gel electrophoresis of plasmid $p B R 322$ DNA; incubation time $=1 \mathrm{~h}$, at $37{ }^{\circ} \mathrm{C}$ in the dark. TBE buffer, $\mathrm{pH}=8.2$. Form I supercoiled DNA, form II - nicked circular plasmid DNA. Complex 1: Lane 1 - DNA control, lane 2 - DNA + $1(20 \mu \mathrm{M})$, lane 3 - DNA + 1 $(40 \mu \mathrm{M})$, lane $4-\mathrm{DNA}+1(60 \mu \mathrm{M})$, lane $5-\mathrm{DNA}+1(80 \mu \mathrm{M})$, lane $6-$ DNA + $1(100 \mu \mathrm{M})$, lane 7 - DNA + $1(120 \mu \mathrm{M})$, lane 8 - DNA + 1 $(140 \mu \mathrm{M})$, lane 9 - DNA $+1(160 \mu \mathrm{M})$, lane $10-\mathrm{DNA}+1(200 \mu \mathrm{M})$.

worthy that $\mathbf{1}$ is more efficient in forming positive supercoils (Fig. 5, lane 8, $140 \mu \mathrm{M}$ ) than 2 (Fig. 6, lane 12, $200 \mu \mathrm{M}$ ), and even higher concentrations are required for 3 (Fig. 7) to induce positive supercoils in DNA. Similar results were noted for cisplatin analogues. ${ }^{58,59}$ Thus, it can be assumed that 1-3 bind covalently to the DNA. In these studies, as well as in the 
$\begin{array}{lllllllllllll}1 & 2 & 3 & 4 & 5 & 6 & 7 & 8 & 9 & 10 & 11 & 12 & 13\end{array}$

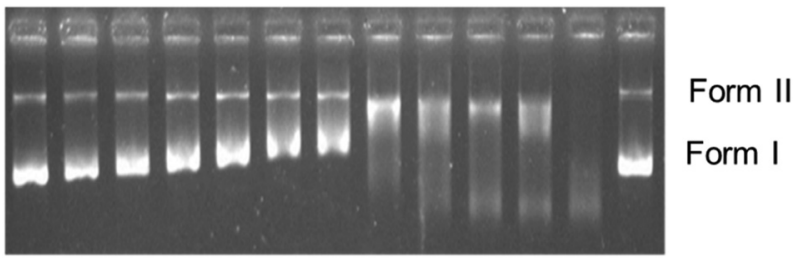

Fig. 6 Agarose (1\%) gel electrophoresis of plasmid $p B R 322$ DNA; incubation time $=1 \mathrm{~h}$, at $37^{\circ} \mathrm{C}$ in the dark. TBE buffer, $\mathrm{pH}=8.2$. Form I supercoiled DNA, form II - nicked circular plasmid DNA. Complex 2: Lane 1 - DNA control, lane 2 - DNA + $2(10 \mu \mathrm{M})$, lane 3 - DNA + 2 $(20 \mu \mathrm{M})$, lane $4-\mathrm{DNA}+2(40 \mu \mathrm{M})$, lane $5-\mathrm{DNA}+2(60 \mu \mathrm{M})$, lane $6-$ DNA + $2(80 \mu \mathrm{M})$, lane $7-\mathrm{DNA}+2(100 \mu \mathrm{M})$, lane 8 - DNA + $2(120 \mu \mathrm{M})$, lane 9 - DNA + $2(140 \mu \mathrm{M})$, lane $10-\mathrm{DNA}+2(160 \mu \mathrm{M})$, lane 11 - DNA $+2(180 \mu \mathrm{M})$, lane $12-\mathrm{DNA}+2(200 \mu \mathrm{M})$, lane $13-\mathrm{DNA}$ control.

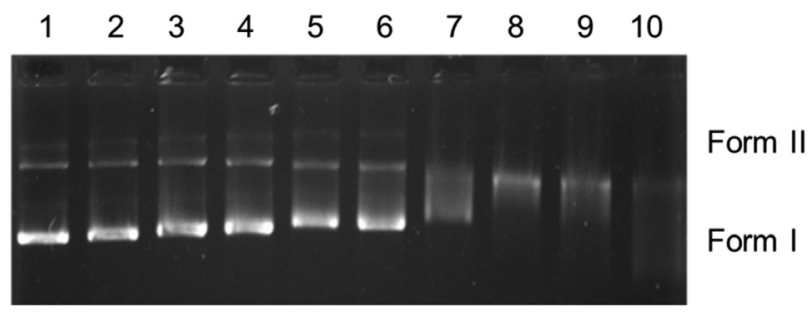

Fig. 7 Agarose (1\%) gel electrophoresis of plasmid pBR322 DNA; incubation time $=1 \mathrm{~h}$, at $37{ }^{\circ} \mathrm{C}$ in the dark. TBE buffer, $\mathrm{pH}=8.2$. Form I supercoiled DNA, form II - nicked circular plasmid DNA. Complex 3: Lane 1 - DNA control, lane 2 - DNA + $3(20 \mu \mathrm{M})$, lane 3 - DNA + 3 $(40 \mu \mathrm{M})$, lane $4-\mathrm{DNA}+3(60 \mu \mathrm{M})$, lane $5-\mathrm{DNA}+3(80 \mu \mathrm{M})$, lane $6-$ $\mathrm{DNA}+3(100 \mu \mathrm{M})$, lane 7 - DNA + $3(120 \mu \mathrm{M})$, lane 8 - DNA + 3 $(140 \mu \mathrm{M})$, lane $9-\mathrm{DNA}+3(160 \mu \mathrm{M})$, lane $10-\mathrm{DNA}+3(200 \mu \mathrm{M})$.

present experiment, the migration rate of supercoiled DNA (form I) decreases until it completely converts into the open circular form. After lane 7, the rate of migration begins to increase again, similar to the supercoiled form (lane 8 and 9).

The cationic complexes $\mathbf{4}$ and $\mathbf{6}$ are structurally different from 1-3, as they have a bidentate pyridine derivative and one chlorido ligand. Complexes 4 and 6 did not show any DNA cleavage in the dark (Fig. SI- $4 \dagger$ ). Contrary to this, after exposure to UVA light (365 nm) for $1 \mathrm{~h}$, only 6 shows a regular decrease in the mobility of form I (Fig. SI-5†) with increasing concentration. These results are similar to those obtained for 1-3 in the dark. It is assumed that photoexcitation facilitates hydrolysis of the monochlorido species to a monoaquo species facilitating adduct formation with DNA leading to local unwinding and retarded mobility at lower concentration (Fig. SI-5, $\dagger$ lane $8,50 \mu \mathrm{M}$ ).

In summary, the electrophoretic mobility studies confirm covalent binding of 1-3 in the dark, while complexes 4 and 6 bind covalently on irradiation.

Cytotoxicity studies. The cytotoxicity of the ruthenium complexes 1-4 and $\mathbf{6}$ and the corresponding ligands $\mathbf{A}-\mathbf{E}$ were studied with several human cancer cell lines derived from different tissues. Cells were exposed to each compound in a
Table $3 \quad I C_{50}$ values $(\mu \mathrm{M})$ of the ruthenium(II) arene complexes 1-4 and 6, ligands A-E and cisplatin

\begin{tabular}{lllll}
\hline & $8505 \mathrm{C}$ & $\mathrm{MCF}-7$ & $\mathrm{SW}-480$ & $518 \mathrm{~A} 2$ \\
\hline $\mathbf{1}$ & $>100$ & $>100$ & $>100$ & $>100$ \\
$\mathbf{2}$ & $69.1 \pm 2.5$ & $36.3 \pm 2.6$ & $94.1 \pm 8.3$ & $97.7 \pm 3.2$ \\
$\mathbf{3}$ & $90.2 \pm 13.9$ & $42.5 \pm 0$ & $>100$ & $>100$ \\
$\mathbf{4}$ & $>100$ & $>100$ & $>100$ & $>100$ \\
$\mathbf{6}$ & $>100$ & $>100$ & $>100$ & $>100$ \\
$\mathbf{A}$ & $>100$ & $>100$ & $>100$ & $>100$ \\
$\mathbf{B}$ & $79.6 \pm 4.5$ & $20.2 \pm 3.5$ & $91.1 \pm 4.9$ & $>100$ \\
C & $>100$ & $55.8 \pm 0.3$ & $>100$ & $>100$ \\
D & $>100$ & $>100$ & $>100$ & $>100$ \\
E & $58.2 \pm 11.6$ & $>100$ & $44.1 \pm 5.1$ & $40.5 \pm 4.5$ \\
Cisplatin & $4.8 \pm 0.1$ & $2.2 \pm 0.2$ & $3 \pm 0.4$ & $2 \pm 0.4$ \\
\hline
\end{tabular}

wide range of doses, and cell viability was determined after $96 \mathrm{~h}$ using an SRB assay (Fig. SI-6 and SI-7†), which revealed different sensitivity of the cancer cells to the applied treatments. The most sensitive were MCF-7 cells, while 8505C, SW-480 and 518A2 were almost resistant (Table 3). This phenomenon is probably related with cell specificity. Interestingly, among all tested ligands only $\mathbf{B}$ and $\mathbf{E}$ revealed tumoricidal potential comparable to the $\mathrm{Ru}$ complexes. $\mathrm{IC}_{50}$ values of complexes 1-4 and 6 are remarkably higher than those obtained with the reference compound cisplatin. ${ }^{66}$ In addition, complex 2 was more effective than 3 , while compounds $\mathbf{1}, \mathbf{4}$ and 6 showed no antitumour activity (Table 3). Therefore, more detailed mechanistic investigations were conducted with the most efficient compound 2 and the MCF-7 cell line.

A relationship between decrease of cell viability and dose as well as an evident plateau effect indicated that complex 2 affected cellular proliferation. Cell staining with CFSE was used to explore the influence of 2 on cell division. According to the obtained data (Fig. 8A), complex 2 resulted in strongly
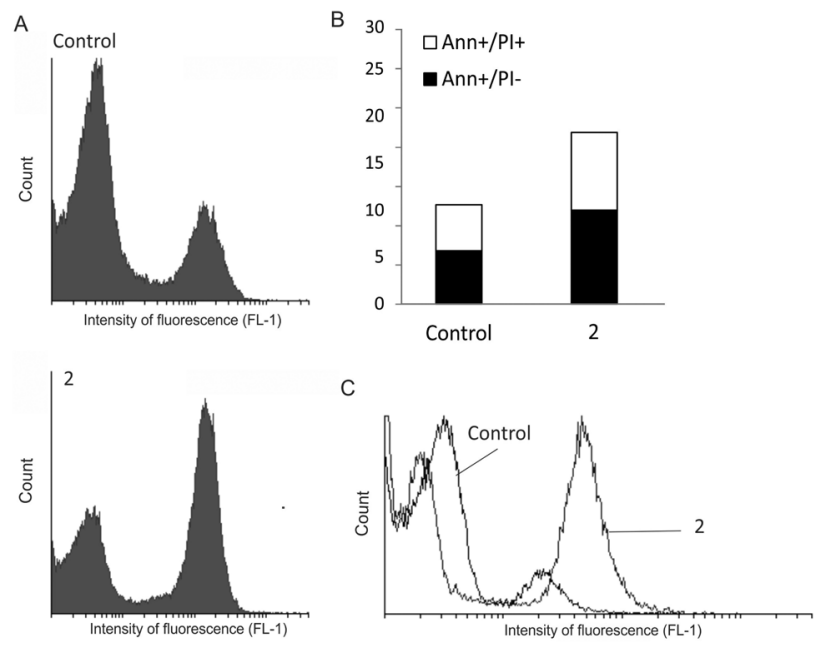

Fig. 8 Influence of $\mathrm{Ru}^{\prime \prime}$ arene complex 2 on cellular proliferation and cell death. MCF-7 cells were treated with $\mathrm{Ru}^{\prime \prime}$ arene complex 2 (IC $_{50}$ value) and flow-cytometric analysis was performed. (A) Inhibition of cell proliferation, (B) induction of apoptosis and (C) caspase activation. 
suppressed proliferation, manifested by a larger quantity of undivided cells in comparison to the control culture. As induction of apoptotic cell death is the typical profile of cytostatic drug action, the presence of apoptotic cell death in cultures exposed to 2 was estimated by Ann/PI double staining. Flowcytometric analysis of cells after $72 \mathrm{~h}$ of treatment revealed moderate accumulation of Ann+/PI- cells, recognised as early apoptotic as well as double positive, necrotic cells (Fig. 8B). This process was synchronised with enhanced caspase activation (Fig. 8C). Taken together, the anticancer capacity of newly synthesised complex 2 is basically related to inhibition of cell proliferation and subsequent caspase-dependent apoptosis. Similar $\mathrm{Ru}^{\mathrm{II}}$ complexes of the general formula $[\mathrm{Ru}(p$ cym $\left.) \mathrm{Cl}_{2}(\mathrm{~L})\right](\mathrm{L}=$ amine ligand $)$ induced cell death via inhibition of DNA synthesis. ${ }^{67}$ The proposed mechanism of $\mathrm{Ru}^{\mathrm{II}}$ arene complexes, primarily based on inhibition of cellular proliferation with moderate caspase-dependent apoptosis, can explain higher $\mathrm{IC}_{50}$ values than determined for cisplatin, which is a cytocidal agent. ${ }^{68}$

\section{Conclusions}

Several $\mathrm{Ru}^{\mathrm{II}}$ arene complexes with mono- and bidentate $\mathrm{N}$-donor ligands were synthesised and characterised by analytical and structural methods. The single-crystal X-ray structure analyses showed complexes 2-6 to have distorted piano-stool geometry. Several spectral, thermal and hydrodynamic measurements of the interaction of complexes 1-4 and 6 with calf thymus DNA indicated covalent binding to DNA. Complexes 1-3 bind covalently to DNA in the dark, similar to cisplatin, while the cationic complexes $\mathbf{4}$ and $\mathbf{6}$ covalently bind to DNA on irradiation, similar to cisplatin analogues. Complexes 2 and 3 are cytotoxic against various cell lines, with highest efficacy for MCF-7 cells. In parallel, ligands $\mathbf{B}$ and $\mathbf{E}$ revealed cytotoxicity against almost all tested cell lines. This antitumour activity was shown to be preferentially realised through inhibition of cell division accompanied by caspasedependent apoptosis.

\section{Acknowledgements}

Financial support from the Free State of Saxony (project number 100099597) and the Graduate School "Leipzig School of Natural Sciences - Building with Molecules and Nano-objects" (BuildMoNa) is gratefully acknowledged (E. H.-H., S. R.). A. S. K. and E. H.-H. thank the DST and DAAD for financial support of a joint Indo-German research project (INT/ FRG/DAAD/P-225/2013). A. S. K. and A. A. K. thank DST (FIST, PURSE) and UGC (CAS) for funding of the Department of Chemistry, SPPU. D. M.-I., D. D. and S. M. would like to acknowledge financial support from the DAAD (PPP project) and the Ministry of Education, Science and Technological Development of the Republic of Serbia (project No. 173013).

\section{Notes and references}

1 S. Medici, M. Peana, V. M. Nurchi, J. I. Lachowicz, G. Crisponi and M. A. Zoroddu, Coord. Chem. Rev., 2015, 284, 329.

2 R. Trondl, P. Heffeter, C. R. Kowol, M. A. Jakupec, W. Berger and B. K. Keppler, Chem. Sci., 2014, 5, 2925.

3 E. Alessio, G. Mestroni, A. Bergamo and G. Sava, Curr. Top. Med. Chem., 2004, 4, 1525.

4 A. Bergamo and G. Sava, Dalton Trans., 2007, 1267.

5 G. Sava, A. Bergamo, S. Zorzet, B. Gava, C. Casarsa, M. Cocchietto, A. Furlani, V. Scarcia, B. Serli, E. Iengo, E. Alessio and G. Mestroni, Eur. J. Cancer, 2002, 38, 427.

6 M. A. Jakupec, M. Galanski, V. B. Arion, C. G. Hartinger and B. K. Keppler, Dalton Trans., 2008, 183.

7 G. Sava and A. Bergamo, Int. J. Oncol., 2000, 17, 353.

8 I. Bratsos, T. Gianferrara, E. Alessio, C. G. Hartinger, M. A. Jakupec and B. K. Keppler, in Bioinorganic Medicinal Chemistry, Wiley Online Library, 2011, 151.

9 A. Vacca, M. Bruno, A. Boccarelli, M. Coluccia, D. Ribatti, A. Bergamo, S. Garbisa, L. Sartor and G. Sava, Br. J. Cancer, 2002, 86, 993.

10 B. K. Keppler, M. Henn, U. M. Juhl, M. R. Berger, R. Niebl and F. E. Wagner, Prog. Clin. Biochem. Med., 1989, 10, 41.

11 G. Sava, E. Alessio, A. Bergamo and G. Mestroni, Topics in Biological Inorganic Chemistry, ed. M. J. Clarke and P. J. Sadler, Springer-Verlag, Berlin, 1999, vol. 1, p. 143.

12 A. Bergamo, S. Zorzet, B. Gava, A. Sorc, E. Alessio, E. Iengo and G. Sava, Anti-Cancer Drugs, 2000, 11, 665.

13 J. M. Rademaker-Lakhai, D. Van Den Bongard, D. Pluim, J. H. Beijnen and J. H. M. Schellens, Clin. Cancer Res., 2004, 10, 3717.

14 M. Groessl, C. G. Hartinger, K. Połeć-Pawlak, M. Jarosz, P. J. Dyson and B. K. Keppler, Chem. Biodiversity, 2008, 5, 1609.

15 P.-S. Kuhn, V. Pichler, A. Roller, M. Hejl, M. A. Jakupec, W. Kandioller and B. K. Keppler, Dalton Trans., 2015, 44, 659.

16 D. S. Thompson, G. J. Weiss, S. Fields Jones, H. A. Burris, R. K. Ramanathan, J. R. Infante, A. Ogden and D. D. von Hoff, J. Clin. Oncol., 2012, 30, 2678.

17 P. Schluga, C. G. Hartinger, A. Egger, E. Reisner, M. Galanski, M. A. Jakupec and B. K. Keppler, Dalton Trans., 2006, 1796.

18 S. K. Singh and D. S. Pandey, RSC Adv., 2014, 4, 1819.

19 M. R. Gill and J. A. Thomas, Chem. Soc. Rev., 2012, 41, 3179.

20 B. M. Zeglis, V. C. Pierre and J. K. Barton, Chem. Commun., 2007, 4565.

21 V. Fernandez-Moreira, F. L. Thorp-Greenwood and M. P. Coogan, Chem. Commun., 2010, 46, 186.

22 L. D. Dale, J. H. Tocher, T. M. Dyson, D. I. Edwards and D. A. Tocher, Anti-Cancer Drug Des., 1992, 7, 3.

23 W. S. Sheldrick and S. Heeb, Inorg. Chim. Acta, 1990, 168, 93. 
24 R. E. Morris, R. E. Aird, P. S. Murdoch, H. Chen, J. Cummings, N. D. Hughes, S. Pearsons, A. Parkin, G. Boyd, D. I. Jodrell and P. J. Sadler, J. Med. Chem., 2001, 44, 3616.

25 N. P. E. Barry and P. J. Sadler, Chem. Commun., 2013, 49, 5106.

26 A. F. A. Peacock and P. J. Sadler, Chem. - Asian J., 2008, 3, 1890.

27 A. L. Noffke, A. Habtemariam, A. M. Pizarro and P. J. Sadler, Chem. Commun., 2012, 48, 5219.

28 C. G. Hartinger, M. Groessl, S. M. Meier, A. Casini and P. J. Dyson, Chem. Soc. Rev., 2013, 42, 6186.

29 C. G. Hartinger, N. Metzler-Nolte and P. J. Dyson, Organometallics, 2012, 31, 5677.

30 P. J. Dyson and G. Sava, Dalton Trans., 2006, 1929.

31 K. J. Kilpin, S. M. Cammack, C. M. Clavel and P. J. Dyson, Dalton Trans., 2013, 42, 2008.

32 N. Busto, J. Valladolid, C. Aliende, F. A. Jalon, B. Manzano, A. M. Rodríguez, J. F. Gaspar, C. Martins, C. T. Biver, G. Espino, J. M. Leal and B. García, Chem. - Asian J., 2012, $12,788$.

33 N. Busto, J. Valladolid, M. Martínez-Alonso, H. J. Lozano, F. A. Jalon, B. R. Manzano, A. M. Rodríguez, M. C. Carrion, T. Biver, J. M. Leal, G. Espino and B. García, Inorg. Chem., 2013, 52, 9962.

34 J. Valladolid, C. Hortiguela, N. Busto, G. Espino, A. M. Rodríguez, J. M. Leal, F. A. Jalon, B. R. Manzano, A. Carbayo and B. García, Dalton Trans., 2014, 43, 2629.

35 C. Aliende, M. Perez-Manrique, F. A. Jalon, B. R. Manzano, A. M. Rodriguez, J. V. Cuevas, G. Espino, M. A. Martınez, A. Massaguer, M. Gonzalez-Bartulos, R. de Llorens and V. J. Moreno, J. Inorg. Biochem., 2012, 117, 171.

36 M. Martínez-Alonso, N. Busto, F. A. Jalon, B. R. Manzano, J. M. Leal, A. M. Rodríguez, B. García and G. Espino, Inorg. Chem., 2014, 53, 11274.

37 T. Wang, Y. Hou, Y. Chen, K. Li, X. Cheng, Q. Zhou and X. Wang, Dalton Trans., 2015, 44, 12726.

38 K. Purkait, S. Karmakar, S. Bhattacharyya, S. Chatterjee, S. K. Dey and A. Mukherjee, Dalton Trans., 2015, 44, 5969.

39 R. Pettinari, C. Pettinari, F. Marchetti, C. M. Clavel, R. Scopelliti and P. J. Dyson, Organometallics, 2013, 32, 309.

40 R. Pettinari, F. Marchetti, C. Pettinari, A. Petrini, R. Scopelliti, C. M. Clavel and P. J. Dyson, Inorg. Chem., 2014, 53, 13105.

41 F. Barragán, P. López-Senín, L. Salassa, S. Betanzos-Lara, A. Habtemariam, V. Moreno, P. J. Sadler and V. Marchán, J. Am. Chem. Soc., 2011, 133, 14098.

42 R. Frank, V. M. Ahrens, S. Boehnke, A. G. Beck-Sickinger and E. Hey-Hawkins, ChemBioChem, 2016, 17, 308.

43 M. A. Bennett and A. K. Smith, J. Chem. Soc., Dalton Trans., $1974,233$.

44 K. Hino, H. Nakamura, Y. Nagai, H. Uno and H. Nishimura, J. Med. Chem., 1983, 26, 222.
45 X. Wang and J. J. Vittal, Inorg. Chem., 2003, 42, 5135.

46 A. Bacchi, G. Cantoni, M. Granelli, S. Mazza, P. Pelagatti and G. Rispoli, Cryst. Growth Des., 2011, 11, 5039.

47 CrysAlis Pro: Data collection and data reduction software package, Rigaku Corp.

48 SIR92: A. Altomare, G. Cascarano, C. Giacovazzo, A. Guagliardi, M. C. Burla, G. Polidori and M. Camalli, J. Appl. Crystallogr., 1994, 27, 435.

49 SHELX: G. M. Sheldrick, Acta Crystallogr., Sect. C: Cryst. Struct. Commun., 2015, 71, 3.

50 K. Brandenburg, Diamond, Version 3.2i, Crystal Impact, GbR, Bonn, Germany.

51 S. S. Bhat, A. S. Kumbhar, A. A. Kumbhar and A. Khan, Chem. - Eur. J., 2012, 18, 16383.

52 S. Bhat, A. S. Kumbhar, A. A. Kumbhar, A. Khan, P. Lönnecke and E. Hey-Hawkins, Chem. Commun., 2011, 47, 11068.

53 H. S. Sahoo, D. Tripathy, S. Chakrabortty, S. S. Bhat, A. Kumbhar and D. K. Chand, Inorg. Chim. Acta, 2013, 400, 42.

54 G. Ludwig, I. Ranđelović, D. Maksimović-Ivanić, S. Mijatović, M. Z. Bulatović, D. Miljković, M. Korb, H. Lang, D. Steinborn and G. N. Kaluđerović, ChemMedChem, 2014, 9, 1586.

55 D. Maksimović-Ivanić, S. Mijatović, I. Mirkov, S. StošićGrujičić, D. Miljković, T. J. Sabo, V. Trajković and G. N. Kaluđerović, Metallomics, 2012, 4, 1155.

56 D. Maksimovic-Ivanic, S. Mijatovic, D. Miljkovic, L. Harhaji- Trajkovic, G. Timotijevic, M. Mojic, D. Dabideen, K. F. Cheng, J. A. McCubrey, K. Mangano, Y. Al-Abed, M. Libra, G. Garotta, S. Stosic- Grujicic and F. Nicoletti, Mol. Cancer Ther., 2009, 8, 1169.

57 T. Eichhorn, E. Hey-Hawkins, D. Maksimović-Ivanić, M. Mojić, J. Schmidt, S. Mijatović, H. Schmidt and G. N. Kaluđerović, Appl. Organomet. Chem., 2015, 29, 20.

58 G. N. Kaluđerović, T. Krajnović, M. Momcilovic, S. StosicGrujicic, S. Mijatović, D. Maksimović-Ivanić and E. HeyHawkins, J. Inorg. Biochem., 2015, 153, 315.

59 J. Gomez, G. Garcia-Herbosa, J. V. Cuevas, A. Arnaiz, A. Carbayo, A. Munoz, L. Falvello and P. E. Fanwick, Inorg. Chem., 2006, 45, 2483.

60 R. Aronson, M. R. J. Elsegood, J. W. Steed and D. A. Tocher, Polyhedron, 1991, 10, 1727.

61 G. A. Jeffrey, An Introduction to Hydrogen Bonding, Oxford University Press, Oxford, 1997.

62 D. A. Tocher and M. D. Walkinshaw, Acta Crystallogr., Sect. B: Struct. Crystallogr. Cryst. Chem., 1982, 38, 3083 (with $\mathrm{BPh}_{4}$ as anion); T. Sumiyoshi, T. B. Gunnoe, J. L. Petersen and P. D. Boyle, Inorg. Chim. Acta, 2008, 361, 3254 (with $\mathrm{B}\left\{3,5-\left(\mathrm{CF}_{3}\right)_{2} \mathrm{C}_{6} \mathrm{H}_{3}\right\}_{4}$ as anion $)$.

63 M. J. Chow, C. Licona, D. Y. Q. Wong, G. Pastorin, C. Gaiddon and W. H. Ang, J. Med. Chem., 2014, 57, 6043.

64 B. M. Zeglis, V. C. Pierre and J. K. Barton, Chem. Commun., $2007,4565$. 
65 H. Song, J. T. Kaiser and J. K. Barton, Nat. Chem., 2012, 4, 615.

66 B. Rosenberg, Cisplatin - Chemistry and Biochemistry of a Leading Anticancer Drug, ed. B. Lippert, Verlag Helvetica Chimica Acta, Zürich, 2nd edn, 1999.
67 W. M. Motswainyana and P. A. Ajibade, Adv. Chem., 2015, 859730.

68 S. Gómez-Ruiz, D. Maksimović-Ivanić, S. Mijatović and G. N. Kaluđerović, Bioinorg. Chem. Appl., 2012, 140284 . 